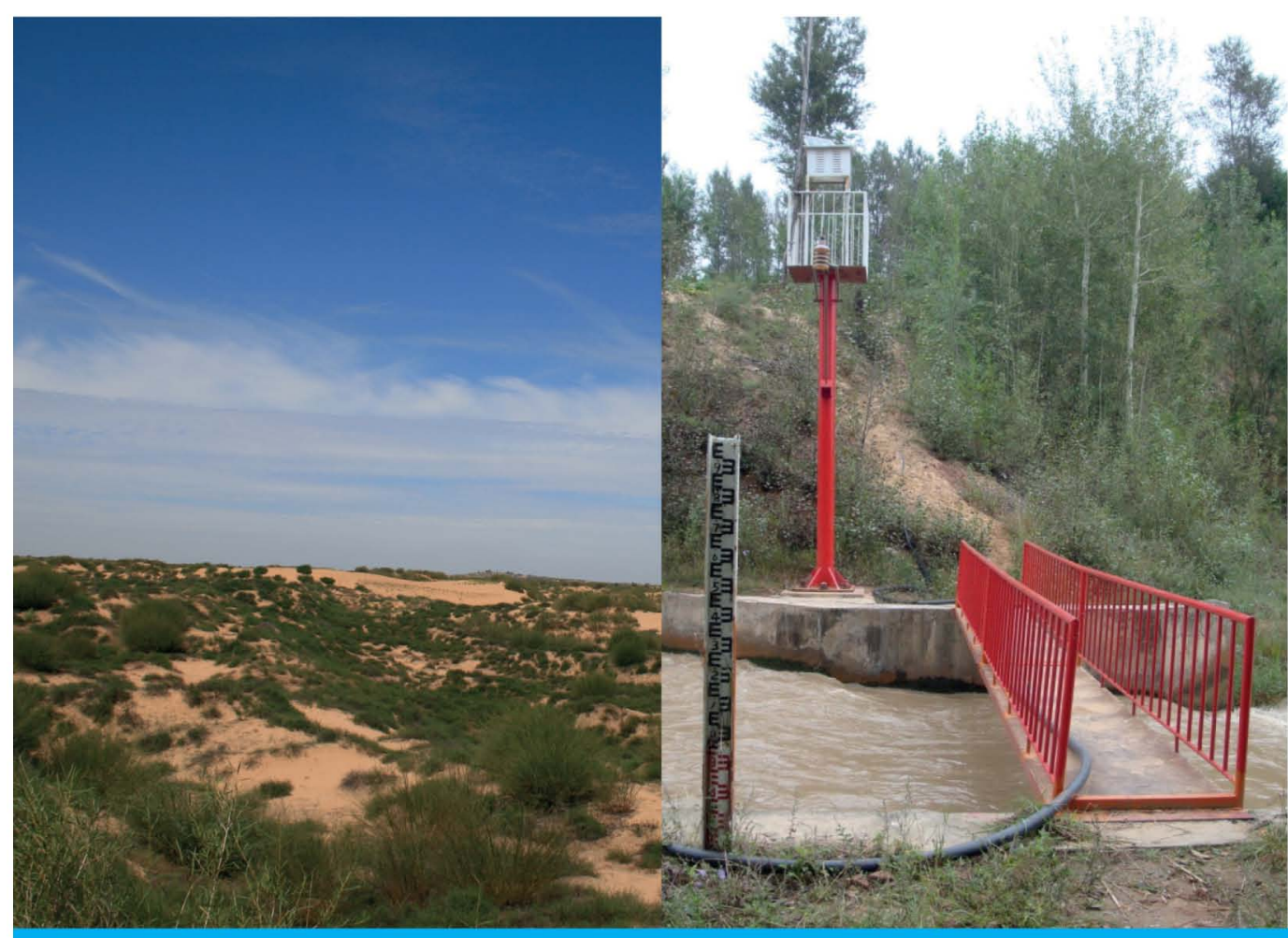

Quantitative Assessment of Groundwater and Surface Water Interactions in the Hailiutu River Basin, Erdos Plateau, China

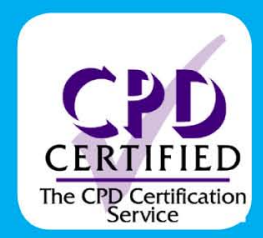

Zhi Yang 
QUANTITATIVE ASSESSMENT OF GROUNDWATER AND SURFACE WATER INTERACTIONS IN THE HAILIUTU RIVER BASIN, ERDOS PLATEAU, CHINA 


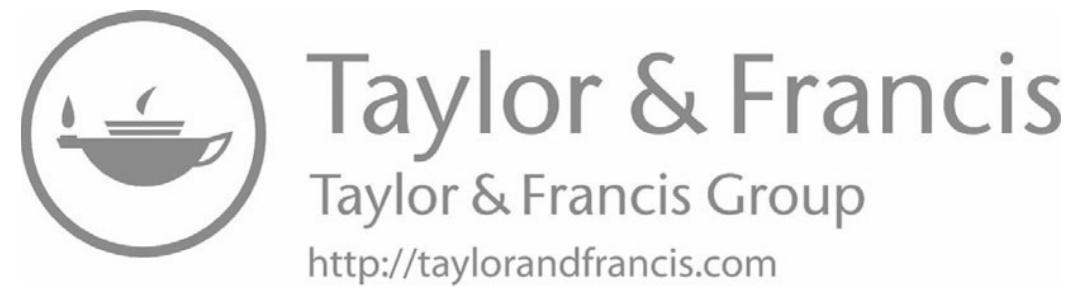




\section{QUANTITATIVE ASSESSMENT OF GROUNDWATER AND SURFACE WATER INTERACTIONS IN THE HAILIUTU RIVER BASIN, ERDOS PLATEAU, CHINA}

\section{DISSERTATION}

Submitted in fulfillment of the requirements of the Board for Doctorates of Delft University of Technology

and

of the Academic Board of the IHE Delft

Institute for Water Education

for

the Degree of DOCTOR

to be defended in public on

Monday, 26 March 2018 at 10.00 hours

in Delft, the Netherlands

by

\section{Zhi YANG}

Master of Science in Hydrology and Water Resources, UNESCO-IHE Institute of Water Education,

Delft, the Netherlands born in Anhui Province, China 
This dissertation has been approved by the promotor: Prof. dr. S. Uhlenbrook copromoter: Dr. Y. Zhou

Composition of the doctoral committee:

Rector Magnificus

Prof. dr. ir. E.J. Moors

Prof. dr. S. Uhlenbrook

Dr. Y. Zhou

Independent members:

Prof. dr. Z. Su

Prof. dr. X. Wang

Prof. dr. ir. F.C. van Geer

Prof. dr. ir. T.N. Olsthoorn

Prof. dr. ir. M.E. McClain
Chairman

Vice-Chair IHE Delft

Delft University of Technology/IHE Delft

IHE Delft

Twente University/ITC

China University of Geosciences, Beijing, China

Utrecht University

Delft University of Technology

IHE Delft/Delft University of Technology, reserve member

This research was conducted under the auspices of the Graduate School for Socio-Economic and Natural Sciences of the Environment (SENSE)

CRC Press/Balkema is an imprint of the Taylor \& Francis Group, an informa business

\section{(C) 2018, Zhi YANG}

Although all care is taken to ensure integrity and the quality of this publication and the information herein, no responsibility is assumed by the publishers, the author nor UNESCO-IHE for any damage to the property or persons as a result of operation or use of this publication and/or the information contained herein.

A pdf version of this work will be made available as Open Access via http://repository.tudelft.nl/ihe This version is licensed under the Creative Commons Attribution-Non Commercial 4.0 International License, http://creativecommons.org/licenses/by-nc/4.0/

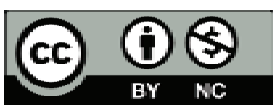

Published by:

CRC Press/Balkema

Schipholweg 107C, 2316 XC, Leiden, the Netherlands

Pub.NL@taylorandfrancis.com

www.crcpress.com - www.taylorandfrancis.com

ISBN 978-1-138-59687-0 


\section{Summary}

Groundwater and surface water have been considered as isolated components of the hydrological cycle for centuries in the application of water resources management. However, groundwater has hydraulic connections with the surface water system and forms a single resource. The interactions between groundwater and surface water comprise complex processes at many different temporal and spatial scales. A growing number of studies on the interactions between groundwater and surface water have been conducted from mountain to flood plain areas in tropical and temperate zones with arid and humid climate. Human activities have interfered with the natural connections between groundwater and surface water according to previous studies. The dynamics of interactions between groundwater and surface water, as well as the response to human interferences, draws our interest towards the influential effects.

The Hailiutu River catchment on the semi-arid Erdos plateau, China, is suffering from the conflicts between the exploitation of water resources for social and economic development and ecosystem protection. The local community has experienced water shortage, groundwater level decline, and ecosystem deterioration in the last several decades. Although groundwater plays a highly important role in the water supply for the local community and sustains the groundwater-dependent ecosystem in the Hailiutu catchment, the interactions between groundwater and surface water, as well as the consequences of human impacts on the hydrological processes, have not been thoroughly elucidated to date. The understanding of the mechanisms associated with the interactions between groundwater and surface water is crucial for achieving sustainable development.

This thesis presents a systematic approach for investigating the interactions between groundwater and surface water, which consists of a statistical analysis of water resources dynamics at the basin level, multiple in-situ observation methods for determining groundwater contributions at a local scale, a simple to complex water balance analysis at the sub-catchment scale, and the quantification of temporal and spatial interactions between groundwater and surface water for the Hailiutu River catchment with tracer and modelling methods.

According to the systemic study of the quantitative assessment of groundwater and surface water interactions in the Hailiutu River catchment, the 
primary contents and conclusions of the thesis are summarized as follows.

First, the importance of interactions between groundwater and surface water, as well as the human impacts at the semi-arid Erdos plateau, China, for sustainable development and ecosystem protection are emphasized. The general background information of the Erdos plateau and the selected Hailiutu River catchment are introduced. The research objectives are identified.

The shifts of stream flow regime at the Hailiutu River were systematically analysed to identify the impacts of different driving forces including climate and human activities. After statistically detecting changes in river discharges, five periods with four major shifts in the flow regime were observed in 1968, 1986, 1992 and 2001. The flow regime reflects the quasi-natural conditions of high variability and larger amplitude of 6-month periodic fluctuations in the period from 1957 to 1967 . The peak flow of the river was reduced by the construction of two reservoirs in the period 1968 to1985. In the period 1986 to 1991, the river discharge further decreased due to the combined influence of river diversions and the increase of groundwater extractions for irrigation. In the fourth period from 1992 to 2000, the river discharge reached its lowest flow and variability, which corresponds to a large increase in crop area. The flow regime recovered in the fifth period from 2001 to 2007 with the implementation of the government policy of returning farmland to forest and grassland, which converts crop land into natural xeric bushland. We identified (or: It was concluded) that climatic elements such as precipitation and air temperature had minor impacts on the flow regime shifts. The construction of the hydraulic works for surface water diversion, groundwater extraction, and the land use policy changes were responsible for flow regime changes in the Hailiutu River catchment.

The second topic focuses on in-situ observations at local scale. The identification and quantification of the interactions between groundwater and surface water at Bulang tributary of the Hailiutu River were conducted by means of hydraulic, temperature, hydrochemistry and isotopic methods with field observations for one year (November 2010 to October 2011). The groundwater discharges to the river dominate the hydrological processes according to the field measurements. The observed groundwater levels were always higher than the river stage, which indicated the groundwater discharge to the river. Temperature measurements of stream water, streambed deposits at different depths, and groundwater confirm the upward flow of groundwater to the stream during all seasons. The results of a tracer-based hydrograph 
separation exercise reveal that, even during heavy rainfall events, groundwater contributes much more to the increased stream discharge than direct surface runoff. Furthermore, groundwater seepage along the reach was quantified with combined river discharge measurements and EC profile measurements under natural condition and constant injection.

To determine the temporal and spatial interactions between groundwater and surface water at the sub-catchment scale, a transient groundwater model with an upscaling procedure combining remote sensing data and field observations for the Bulang sub-catchment was constructed. The catchment water balance was analysed by considering vegetation types with the Normalized Difference Vegetation Index (NDVI), determining evaporation rates by combining sap flow measurements and NDVI values, recorded precipitation, measured river discharge and groundwater levels from November 2010 to October 2011. A comparison between a simple water balance computation, a steady state groundwater flow model, and the transient groundwater flow model indicated that different land use scenarios would result in different river discharges. It was shown that $91 \%$ of the precipitation was consumed by the crops, bushes and trees; only $9 \%$ of the annual precipitation became net groundwater recharge, which maintained a stable stream discharge during the year with observations. Four land use scenarios were analysed as (1) the quasi natural state of the vegetation covered by desert bushes; (2) the current land use/vegetation types; (3) the change of crop types to dry resistant crops; and (4) the ideal land use covered by dry resistant crops and desert bushes. These four scenarios were simulated and compared with the measured data from 2011, which was a dry year. Furthermore, scenarios (2) and (4) were evaluated under normal and wet conditions for the years 2009 and 2014, respectively. The simulation results show that dry resistant bushes and certain crops can significantly increase net groundwater recharge, which leads to an increase of groundwater storage and river discharges. The depleted groundwater storage during the dry year could be restored during the normal and wet years such that groundwater provides a reliable resource to sustain river discharge and the dependent vegetation in the area.

The fourth topic presents an investigation of human activities on the interactions between groundwater and surface water in the Hailiutu catchment. The isotopic and chemical analysis of surface water and groundwater samples identified groundwater discharges (seepage?) to the river along the Hailiutu River. Mass balance equations 
with chemical profiles were used to estimate the spatial distribution of groundwater seepage rates along the river. The temporal variations of groundwater and surface water interactions were investigated using the hydrograph separation method. A numerical groundwater model was constructed to simulate groundwater discharges along the river and analyse the effects of water use in the catchment. The simulated seepage rates along the river compare reasonably well with the seepage estimates from the chemical profile measurements in 2012. The impacts of human activities including river water diversion and groundwater abstraction, on river discharge were analysed by calculating the differences between the simulated natural groundwater discharge and the measured river discharge. The water use in the Hailiutu River increased from 1986 to 1991, reached its highest level from 1992 to 2000, and decreased from 2001 onwards. The reduction of river discharge might have had negative impacts on the riparian ecosystem and the water availability for downstream users. Thus, the interactions between groundwater and surface water as well as the consequences of human impacts should be taken into account when implementing sustainable water resources management.

This research has addressed multi-disciplinary topics on hydrology, climate change, land use change and upscaling methods in terms of interactions between groundwater and surface water in the Hailiutu River catchment, Erdos plateau, China. The river flow regime has been intensively influenced by human activities, such as the construction of reservoirs, water diversion, and groundwater exploitation. Since groundwater discharge dominates the overall discharge in the Hailiutu River catchment, the replacement of the current vegetation with less water consuming crops and bushes would increase the groundwater discharge to the river. Hence, the optimized land use would benefit water resources management as well as the ecosystem in the Hailiutu River catchment. The main findings in this study provided valuable insights for the scientific community and sustainable policy making. 


\section{Samenvatting}

Eeuwenlang zijn het grondwater en oppervlaktewater beschouwd als geïsoleerde onderdelen van de hydrologische cyclus bij de toepassing van waterbeheer. Grondwater heeft echter hydraulische connecties met het oppervlaktewater en zij vormen samen een enkel systeem. De interacties tussen het grondwater en oppervlaktewater omvat complexe processen op vele verschillende temporele en ruimtelijke schaalgroottes. Een groeiend aantal studies over de interacties tussen grondwater en oppervlaktewater zijn uitgevoerd in berg en laagland gebieden, zowel in tropische als gematigde zones met verschillende klimatologische omstandigheden. Menselijke activiteiten hebben de natuurlijke connecties tussen grondwater en oppervlaktewater beinvloed. De dynamiek van de interacties tussen het grondwater en oppervlaktewater, evenals de reactie op menselijke verstoringen, wekt onze interesse naar mogelijke effecten.

Het stroomgebied van de Hailiutu rivier dat zich bevindt op het semi-aride Erdos plateau in China, heeft te lijden onder conflicten die verband houden met de exploitatie van watervoorraden voor sociale en economische ontwikkeling aan de ene kant en de bescherming van het ecosysteem anderzijds. In de laatste decennia heeft de lokale gemeenschap te maken gehad met tekorten aan water, dalende grondwaterspiegels, en verslechtering van het ecosysteem. Hoewel grondwater een zeer belangrijke rol in de watervoorziening voor de lokale gemeenschap speelt en het grondwater-afhankelijke ecosysteem in het stroomgebied van de Hailiutu rivier uitermate delicaat is, zijn de interacties tussen grondwater en oppervlaktewater, alsmede de impact die de mens heeft op de hydrologische processen, niet goed onderzocht. Het verkrijgen van inzicht in de mechanismen die de interacties tussen het grondwater en oppervlaktewater aansturen, is van cruciaal belang voor het bereiken van duurzame ontwikkeling.

Deze thesis presenteert een systematische aanpak voor het onderzoeken van de interacties tussen grondwater en oppervlaktewater, bestaande uit een statistische analyse van de dynamiek van water voorkomens op stroomgebiedsniveau, de toepassing van meerdere in-situ methoden voor het uitvoeren van observaties die bijdrages van grondwater op een lokale schaal vaststellen, het uitvoeren van eenvoudige tot complexe analyses op basis van de waterbalansen van 
sub-stroomgebieden, en de kwantificering van temporele en ruimtelijke interacties tussen grondwater en oppervlaktewater voor het hele stroomgebied van de Hailiutu rivier met gebruik making van 'tracer' en modellerings technieken.

Op grond van de uitgevoerde systematische studie naar de de kwantitatieve beoordeling van de interacties tussen grondwater en oppervlaktewater in het stroomgebied van de Hailiutu rivier, kunnen inhoud en conclusies van het proefschrift als volgt worden samengevat.

Ten eerste wordt het belang van interacties tussen grondwater en oppervlaktewater, alsmede de menselijke invloed daarop en de gevolgen voor duurzame ontwikkeling en bescherming van het ecosysteem van het Erdos plateau, benadrukt. Informatie over de algemene achtergrond van het Erdos plateau en het beoogde stroomgebied van de Hailiutu rivier worden geintroduceerd. Vervolgens krijgen de onderzoeksdoelstellingen en de gevolgde methodieken de volle aandacht.

De veranderingen in het afvoer regime van de Hailiutu rivier zijn systematisch geanalyseerd om de effecten van klimaat en menselijke activiteiten vast te stellen. Met statische methodes konden significante veranderingen in het afvoer regime worden bepaald. Dit heeft geresulteerd in het vaststellen van vijf perioden met een typisch afvoer regime aan de hand van vier veranderingen in het afvoer verloop die plaatsvonden in 1968, 1986, 1992 en 2001. Het afvoer regime weerspiegelt de quasi-natuurlijke situatie van hoge variabiliteit en grote amplitudes van de 6 maandelijkse periodieke fluctuaties gedurende de periode van 1957 tot 1967. De hoge afvoeren van de rivier werden afgeroomd in de periode van 1968 tot 1985 door de bouw van twee reservoirs. In de periode van 1986 tot 1991 daalde de afvoer van de rivier verder ten gevolge van de gecombineerde invloed van het aftappen van water uit de rivier en de toename van grondwateronttrekkingen voor irrigatie. In de periode van 1992 tot 2000 was de afvoer van de rivier minimaal zowel met betrekking tot volume als variabiliteit. Deze periode correspondeert met een grote uitbreiding van de landbouwgebieden op het plateau. De afvoeren van de rivier herstelden zich in de periode van 2001 tot 2007 toen regeringsbeleid werd ingevoerd om landbouwgrond te converteren naar natuurlijk bos en grasland. Er kon vastgesteld worden dat klimatologische elementen zoals neerslag en lucht temperatuur maar een zeer klein effect hebben gehad op de veranderingen in het afvoer regime. Het implementeren van hydraulische werken voor de berging en het aftappen van oppervlaktewater, grondwateronttrekkingen, en de aanpassingen in het landgebruik waren 
verantwoordelijk voor de veranderingen van het afvoer regime in het stroomgebied van de Hailiutu rivier.

Het tweede aandachtspunt vormen de in-situ methoden voor het uitvoeren van observaties op lokale schaal. De identificatie en kwantificering van de interacties tussen het grondwater en oppervlaktewater werden uitgevoerd langs de Bulang rivier die een zijrivier is van de Hailiutu rivier. Er is gebruik gemaakt van hydraulische, temperatuur, hydro-chemische en isotopen methodes waarbij de veldmetingen over een periode van een jaar zijn uitgevoerd. Volgens de metingen domineert de grondwater afvoer naar de rivier de hydrologische processen. De waargenomen grondwaterstanden waren altijd hoger dan de waterstand van de rivier en dit indiceert de afvoer van grondwater naar de rivier. Temperatuurmetingen van het rivier water, in het sediment bed van de rivier op verschillende dieptes, en van het grondwater zelf bevestigden de opwaartse stroom van grondwater naar de rivier gedurende alle seizoenen. De resultaten van het onderverdelen van de afvoer hydrograaf op basis van 'tracer' metingen onthulden dat, zelfs tijdens zware regenval, het grondwater meer bijdraagt aan de toegenomen afvoer van de rivier dan het afstromende oppervlaktewater. Bovendien werd de grondwater afvoer langs een geselecteerd lengteprofiel van de rivier gekwantificeerd door afvoermetingen uit te voeren en die te combineren met geleidbaarheid (EC) metingen in het rivier water, onder natuurlijke omstandigheden en na een constante injectie van een 'tracer'.

Om de temporele en ruimtelijke interacties tussen grondwater en oppervlaktewater op de schaalgrootte van een sub- stroomgebied te bepalen, werd een tijdsafhankelijk grondwater model geconstrueerd, voorzien van een opschalingsprocedure die gebruik maakt van tele-detectie gegevens en veldwaarnemingen uit het sub- stroomgebied van de Bulang rivier. De waterbalans van het gebied werd opgemaakt door vegetatietypes te classificeren met de Genormaliseerde Verschil Vegetatie Index (NDVI) methode, en verdampingssnelheden te bepalen door het combineren van 'sap' stroom metingen en NDVI-waarden. Daarnaast werden ook de gemeten neerslag en afvoer van de rivier, alsmede de grondwaterstanden vanaf november 2010 tot en met oktober 2011 in overweging genomen. Door de eenvoudige waterbalans, een tijdsonafhankelijk grondwater model, en het tijdsafhankelijke model met elkaar te vergelijken, kon de conclusie worden getrokken dat verschillen in landgebruik leiden tot verschillende groottes van de afvoer in de rivier. Voor het observatie jaar bleek dat $91 \%$ van de neerslag werd verbruikt door de gewassen, struiken en bomen. Slechts $9 \%$ van de 
jaarlijkse neerslag werd omgezet in grondwateraanvulling, die vervolgens een stabiele afvoer van de rivier garandeerde. Tot slot werden de 4 volgende scenario's voor landgebruik geanalyseerd (1) het landgebruik reflecteert de quasi natuurlijke toestand van een vegetatie dek bestaande uit woestijn struiken; (2) het landgebruik en de vegetatie en gewas typen zien eruit zoals momenteel gangbaar is; (3) de huidige landbouw gewassen worden vervangen door droogte-resistente gewassen; en (4) het ideale landgebruik bestaande uit woestijn struiken en droogte resistente gewassen wordt ingevoerd. Deze vier scenario's werden gesimuleerd met de modellen en vergeleken met meetgegevens uit 2011 dat een droog jaar was. Bovendien werden scenario's (2) en (4) geëvalueerd onder normale en natte omstandigheden waarvoor respectievelijk de jaren 2009 en 2014 als uitgangspunt dienden. De simulatie resultaten laten zien dat woestijn struiken en droogte-resistente gewassen de grondwateraanvulling aanzienlijk verhogen, hetgeen weer leidt tot een toename van de grondwater berging en afvoer in de rivier. De sterk verminderde grondwater berging ontstaan tijdens het droge jaar kon worden hersteld tijdens het normale en natte jaar in die mate dat grondwater een betrouwbare bron van water bleek om de afvoer in de rivier en de grondwater-afhankelijke vegetatie in het gebied te ondersteunen.

Het laatste aandachtspunt behelst het onderzoek naar de effecten van menselijke activiteiten op de interactie tussen het grondwater en oppervlaktewater in het stroomgebied van de Hailiutu. Isotopen en chemische analyses van grondwater en oppervlaktewater monsters toonden wederom de afvoer van grondwater naar de rivier aan. Massabalans vergelijkingen samengesteld op basis van chemische profielen zijn gebruikt om een inschatting te maken van de ruimtelijke spreiding van de afvoer van grondwater langs de loop van de rivier. Temporele variaties in de interacties van grondwater en oppervlaktewater werden onderzocht door gebruik te maken van methodes voor het onderverdelen van de afvoer hydrograaf van de rivier. Grondwater modellering werd ingezet om langs de loop van de rivier de afvoer van grondwater te simuleren en het effect van menselijk water gebruik in het stroomgebied te analyseren. De gesimuleerde afvoeren van grondwater naar de rivier vertonen een redelijke overeenkomst met de geschatte afvoeren gemaakt op basis van de gemeten chemische profielen in 2012. De impact van menselijke activiteiten zoals het aftappen van water uit de rivier of het implementeren van grondwateronttrekkingen, op de afvoer van de rivier werd geanalyseerd door het berekenen van de verschillen tussen de gesimuleerde natuurlijke afvoer van grondwater naar de rivier en de gemeten water afvoer in de rivier. 
Het aftappen van water uit de Hailiutu rivier nam toe van 1986 tot 1991, bereikte een hoogste niveau van 1992 tot 2000 en daalde daarna vanaf 2001. De vermindering van de afvoer van de rivier zou negatieve gevolgen kunnen hebben gehad voor het ecosysteem langs de rivier en de beschikbaarheid van water voor benedenstroomse gebruikers. Met de interacties tussen grondwater en oppervlaktewater, alsmede de gevolgen van menselijke activiteiten moet dus rekening worden gehouden bij de uitvoering van duurzaam waterbeheer.

Dit onderzoek heeft zich geconcentreerd op de inzet van multidisciplinaire onderwerpen op het gebied van de hydrologie, klimaatverandering, landgebruik en opschalingsmethodes om de interacties tussen grondwater en oppervlaktewater te analyseren in het stroomgebied van de Hailiutu rivier op het Erdos plateau in China. Het afvoer regime van de rivier werd ernstig beïnvloed door menselijke activiteiten, zoals de aanleg van stuwmeren, het aftappen van water en het implementeren van grondwateronttrekkingen. Aangezien de afvoer van grondwater de algemene water afvoer in het stroomgebied van de Hailiutu rivier domineert, zou de vervanging van de huidige vegetatie door droogte-resistente gewassen en struiken, de afvoeren doen vergroten. Een geoptimaliseerd landgebruik zou het waterbeheer positief beinvloeden, alsmede het ecosysteem in het stroomgebied van de Hailiutu rivier verbeteren. De belangrijkste bevindingen van deze studie leveren waardevolle inzichten op voor de wetenschappelijke gemeenschap en duurzame beleidsvorming. 


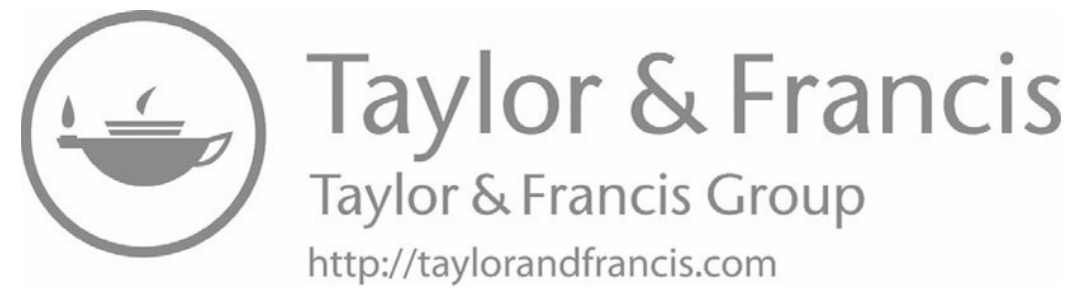




\section{Acknowledgements}

It was a big challenge to do the annual shift between scientific research at UNESCO-IHE in The Netherlands and practical environmental impact assessment consultancy in China during the last 7 years $\mathrm{PhD}$ research. They were full of challenges along with opportunities. Challenges in setting-up the field research site, analysing measurements, and writing scientific articles forced me to develop as scientific researcher. Opportunities in working with renowned experts in the field and meeting fellow students from all over the world were most valuable experiences in this study. I am grateful to those who have contributed to the completion of this thesis.

I am very grateful to my wife Zhou Lingyun, my draught Yang Jingyun, my father and mother, and my parents in law, all of you always support me with the encouragement, and take care of family during my absent.

I would like to express my sincere and deepest appreciations to my co-promoter Dr. Yangxiao Zhou, I could not have finished this $\mathrm{PhD}$ thesis without his continuous, devoted, and careful guidance. Your innovative, critical, and inspiriting supervision are the most reliable and dependable source from the beginning of the research and to my future career.

Many thanks are due to my supervisor Dr. Jochen Wenninger for all help in the field investigation, instrument installation, data analysis at laboratory, and constructive discussions in the study.

My extreme gratitude goes to my promoter Prof. Stefan Uhlenbrook for his helpful, comfortable, and professional support. His wise advice, critical and creative insights, and wealth of broad knowledge had tremendously effects on my study.

I would like to thank Prof. Wan Li, Prof. Wang Xusheng, Prof. Jin Xiaomei, Dr. Chen Jinsong, Prof. Hu Fusheng, Dr. Hou Lizhu, among many others at China University of Geosciences (Beijing) for their support and cooperation. The support from Prof. Xie Yuebo, Prof. Zhang Danrong, Prof. Jiang Cuiling at Hohai University are acknowledged.

Special thanks go to Erdos research team members (Hou Guangcai, Yin Lihe, Huang Jinting, Dong Ying, Chang Liang, Wang Xiaoyong, Dong Jiaqiu) at Xi'an Center of Geological Survey. Without their cooperation and support, I could not 
operate field experimental facilities at the Hailiutu catchment.

Many friends in the Netherlands and China are appreciated for enjoying happy and relaxing times together. They are Li Shengyang, Wang Chunqin, Wan Yuanyang, Guo Leicheng, Yan Kun, Zhu Xuan, Ye Qinghua, Wan Taoping, Xu Zhen, Chen Qiuhan, Chen Hui, Pan Quan, Xu Ming, Wang Wen, Li Hong, Zhang Guoping, Zuo Liqin, Wang Hao, etc. Thank you all for your companion during my stay in Delft.

Finally, financial support of the study is acknowledged: China Scholarship Council, Netherlands Asian facility for China programme, Honor Power Foundation, and IHE Internal Research Fund.

YANG Zhi

Anhui, China

November, 2017 


\section{Contents}

SUMMARY ........................................................................................................................ V

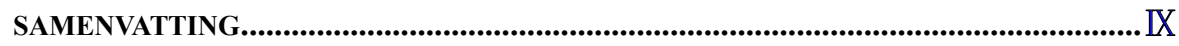

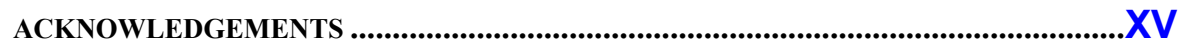

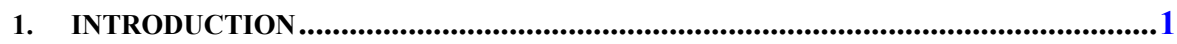

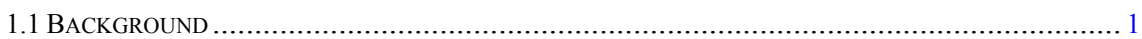

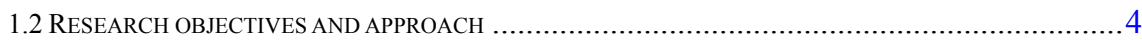

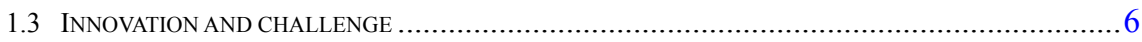

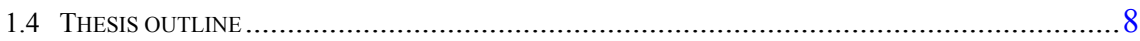

2. THE FLOW REGIME SHIFT IN HAILIUTU RIVER ................................................11

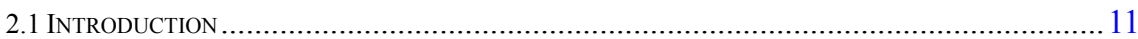

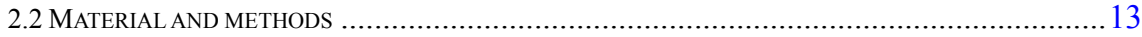

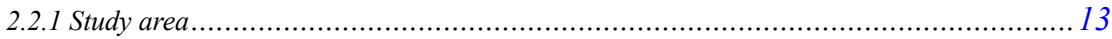

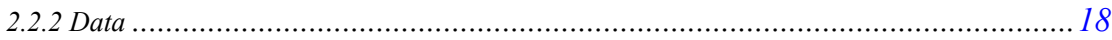

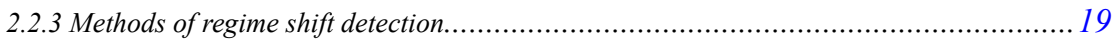

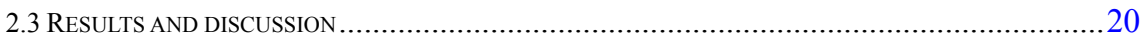

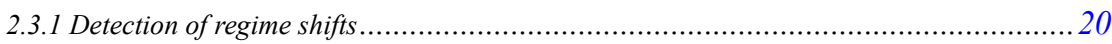

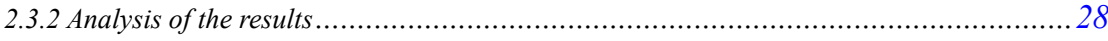

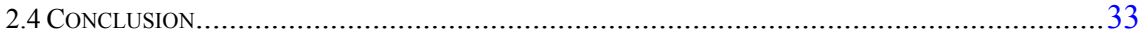

3. A MULTI-METHOD APPROACH TO QUANTIFY GROUNDWATER/SURFACE WATER

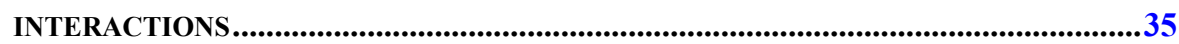

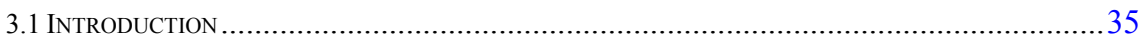

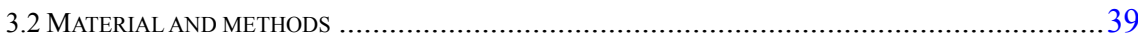

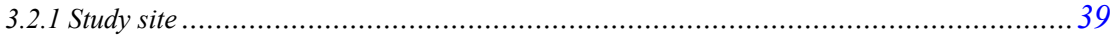

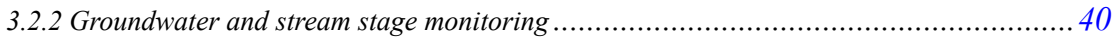

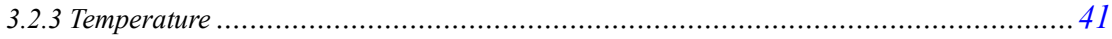

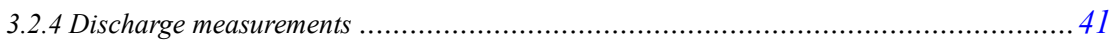

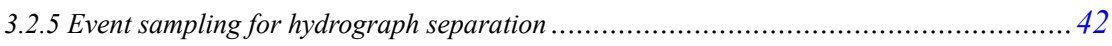


3.2.6 Seepage calculation with electrical conductivity $(E C)$ profile ....................................4 43

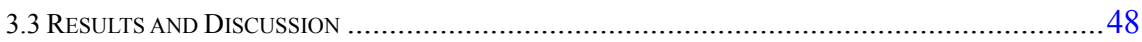

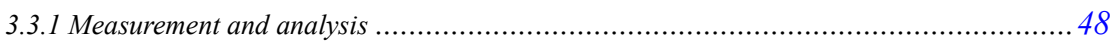

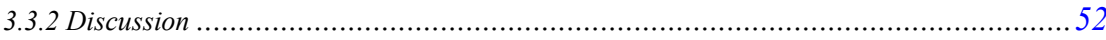

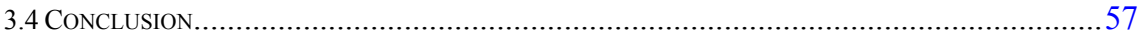

\section{GROUNDWATER-SURFACE WATER INTERACTIONS UNDER DIFFERENT LAND}

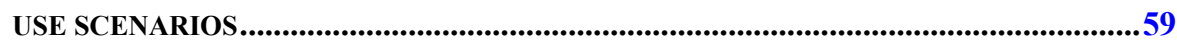

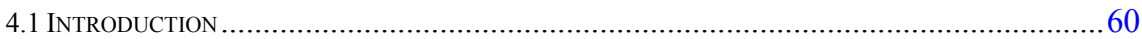

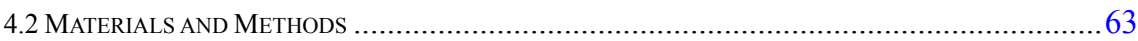

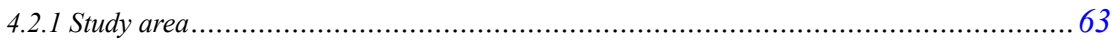

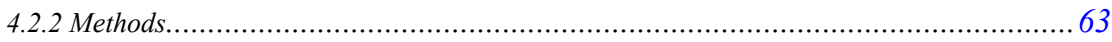

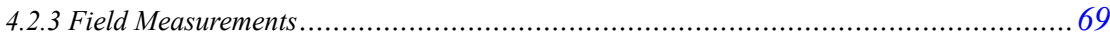

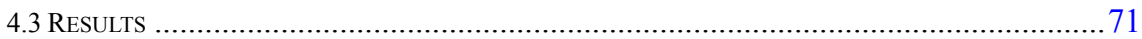

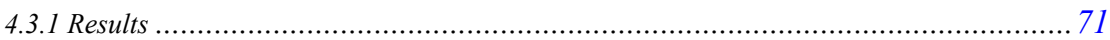

4.3.1.1 Estimation of Catchment water balance ............................................................. 71

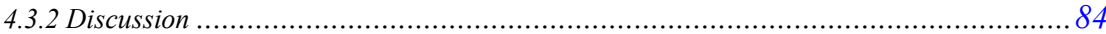

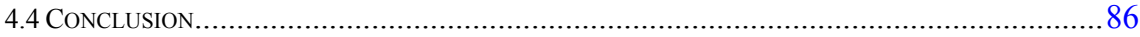

\section{GROUNDWATER AND SURFACE WATER INTERACTIONS AND IMPACTS OF}

HUMAN ACTIVITIES IN THE HAILIUTU CATCHMENT, NORTHWEST CHINA.............89

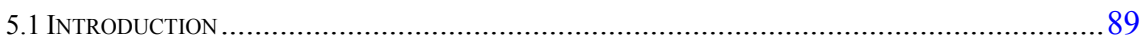

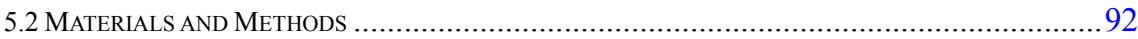

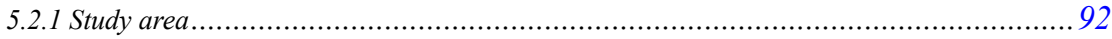

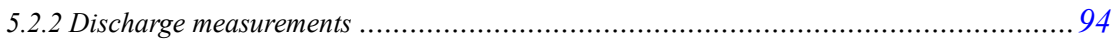

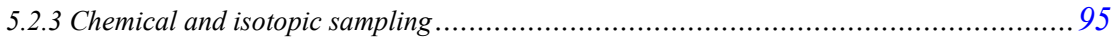

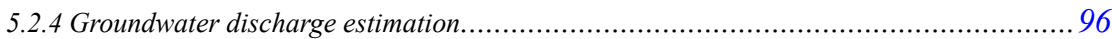

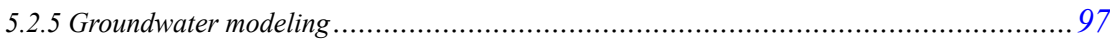

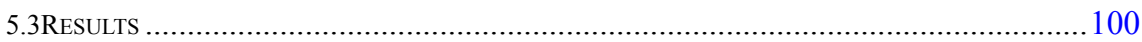

5.3.1 Discharge measurements and baseflow separation.............................................. 100

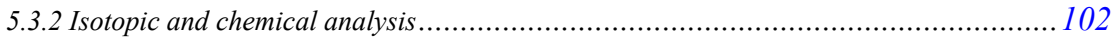

5.3.3 Estimation of groundwater discharge using the $\mathrm{Ct}$ chemical profile ......................... 105

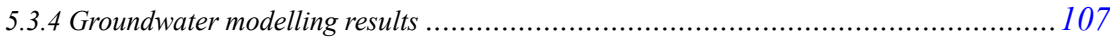

5.3.5 Comparison of seepage estimation and the simulated groundwater discharge............ 108

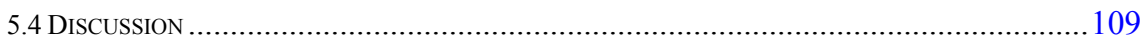


5.5 CONCLUSION.

6 CONCLUSIONS, OUTLOOK AND FUTURE RESEARCH .................................... 113

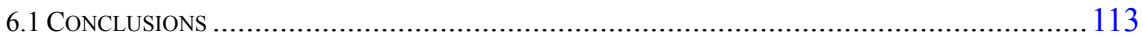

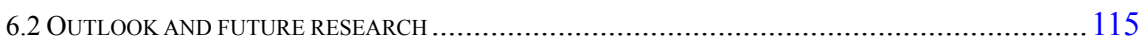

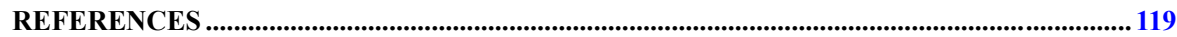

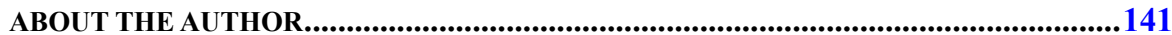




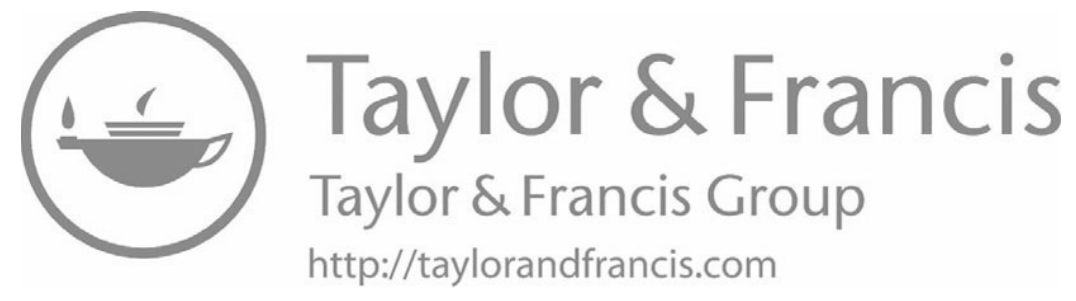




\section{Figures and Tables}

\section{List of figures}

Figure 1.1 Methodologies framework in this study. .7

Figure 2.1 Map of the Hailiutu catchment, the numbers nearby the stations are indices of hydraulic engineering works in the Table 2.1 .14

Figure 2.2 NDVI map of the Hailiutu catchment, interpretation of remote sensing data from TM image, observed on Aug, 2008; see Table 2.2 for the conversion of NDVI values to land cover classes.

Figure 2.3 (a) mean monthly air temperature (2005-2008); (b) Mean monthly precipitation (1984-2005); (c) mean monthly pan evaporation (1984-2005) at Wushenqi meteorological station; and (d) mean monthly discharge at Hanjiamao station (1957-2007), the error bars indicate the standard deviations for precipitation, potential evaporation, air temperature and the percentiles of the discharge .17

Figure 2.4 Flow regime shifts in the annual mean discharge (a), annual maximum discharge (b), annual mean monthly minimum discharge (c), and the annual mean monthly standard deviation (d) at Hanjiamao station from 1957 to 2007, the solid lines are the characteristic series and the dashed lines are the their step trends.

Figure 2.5 Harmonic changes in monthly mean discharge and standard deviation at Hanjiamao station for different periods. .24

Figure 2.6 Flow duration curves for mean daily discharges at Hanjiamao station in the 5 different periods. .26

Figure 2.7 Annual precipitation (a), Heavy precipitation ( $>10 \mathrm{~mm} / \mathrm{d})$ (b), number of days of heavy precipitation (c), annual mean temperature from April to October (d) at meteorological stations from 1961 to 2006. Annual pan evaporation (e) and annual crop area (f) in Yuyang district from 1957 to 2007, the dashed lines are the step trends.

Figure 2.8 Illustration of the causes for regime shifts; the cultivation policy, crop area, annual discharge, and temperature form April to October at Yulin meteorological 
station. .30

Figure 2.9 Fit of prediction by multiple regression of the annual mean discharge at Hanjiamao station with the climatic variables at Yulin station and crop area in Yuyang district from 1968 to 2006 . .32

Figure 3.1 Location of the Yujiawan discharge gauging station, groundwater monitoring wells, rain gauge, and the constant injection point at the Yujiawan stream in the Bulang sub-catchment inside the Hailiutu River basin. .39

Figure 3.2 (a) Schematic plot of the groundwater monitoring wells installed in the Bulang sub-catchment; the dotted blue line indicates groundwater heads in the monitoring wells and the piezometer in the streambed at 20:00 14 June, 2011; (b) the installation of temperature sensors, piezometer in the streambed, and the stilling well for the stream stage registration. .42

Figure 3.3 Plan view of locations of electrical conductivity (EC) measurements in the Yujiawan stream...... .44

Figure 3.4 Schematic plot of mass balance calculations under the natural situation: (a) for the total $180 \mathrm{~m}$ reach and (b) for 10-m segments.

Figure 3.5 Schematic plot of mass balance calculations under constant injection: (a) for the total 180-m reach; and (b) for 10-m segments...... .46

Figure 3.6 Stream discharge at Yujiawan gauging station and rainfall at the rain gauge from 1 November 2010 to 31 October 2011. .48

Figure 3.7 Groundwater levels below the terrace (Well a), flood plain (Well b), stream bank (Well c), and streambed from 1 November 2010 to 31 October 2011

Figure 3.8 (a) Temperature of stream water and stream sediment at 10, 30, 50, and 80-cm depth beneath the stream bed from 1 September 2010 to 31 October 2011. Temperature at the surface of the streambed (right y axis) and at different depths beneath the streambed in (b) winter and (c) summer in 2011. .50

Figure 3.9 (a, b, c) Stable isotope values, hydrochemical behavior of streamflow samples, (d) rainfall and discharge from 1 July to 5 July 2011, and (e) a two-component hydrograph separation using oxygen-18 for the rainfall event that occurred on 2 July 2011

Figure 3.10 Measured natural electrical conductivity (EC) profile and EC values

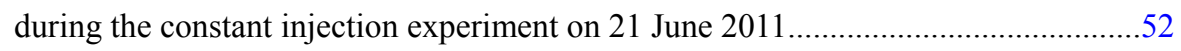

Figure 3.11 Estimation of seepage and discharge along the stream reach..................55

Figure 3.12 Sensitivity of estimated stream discharge to groundwater EC value along XXII 
the stream bank (a) with the natural EC profile method, (b) with the constant injection method. Sensitivity of estimated stream discharge to EC measurement errors (c) with the natural EC profile method, (d) with the constant injection method, and (e, f) with the combined method. .56

Figure 3.13 Sensitivity of estimated stream discharge along the reach to the discharge measurement error at the gauging station using the combined method. .57

Figure 4.1 Location of the Bulang sub-catchment within the Hailiutu basin in Northwest China, the location of sap flow measurements for maize and salix, hydrological and meteorological stations, groundwater level monitoring wells, and the digital elevation model.

Figure 4.2 NDVI map of the Bulang catchment, interpretation of remote sensing data from (TM) image, observed on August 2011

Figure 4.3 Rainfall at Yujiawan and Nanitan station, measured discharge at Yujiawan weir from November 2010 to October 2011. .71

Figure 4.4 Up-scaling approach for areal evapotranspiration with sap flow measurements and NDVI values (a); and the estimated areal evapotranspiration (b).73 Figure 4.5 Comparison of evapotranspiration estimated by remote sensing and calculated by upscaling approach with NDVI and sap flow measurements from

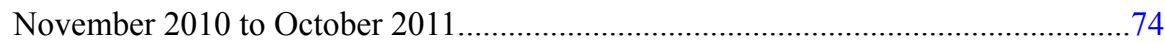

Figure 4.6 Observed groundwater levels in Bulang catchment................................75

Figure 4.7 Average precipitation, river discharge, and estimated ET (a); groundwater storage change (b) in Bulang catchment from November 2010 to October 2011.......76 Figure 4.8 Relations among the observed discharge, separated baseflow, and the rainfall in the Bulang catchment .77

Figure 4.9 Fit of the computed groundwater levels to the measured ones in four wells in Bulang sub-catchment. . .77

Figure 4.10 Comparison of simulated groundwater discharge to the Bulang River and the separated base flow from November 2010 to October 2011 . .78

Figure 4.11 Sensitivity of computed stream discharge (a); and groundwater levels (b-e) to precipitation (P), evapotranspiration (ET), and hydraulic conductivity (HC); the sign $(-)$ and $(+)$ in the legend indicates the decreasing and increasing values by $26.5 \%$.

Figure 4.12 Simulated groundwater discharge to the Bulang River (a); and the calculated groundwater heads in well Blh (b); eco_site (c); well a (d); and well b (e) 
for four land use scenarios

80

Figure 4.13 Simulated groundwater discharge to the Bulang River and calculated groundwater heads with current land use (a2-e2); and Ideal land use scenario (a4-e4) under dry, normal and wet hydrological years.

Figure 4.14 Simulated groundwater discharge to the Bulang River and the monthly rainfall at Wushenqi from 2000 to 2009 (a); the calculated groundwater heads in well Blh (b); eco_site (c); well a (d); and well b (e) for current and ideal land use scenarios from 2000 to 2009 . 84

Figure 5.1 The catchment of the Hailiutu River and measurement/sample locations.94 Figure 5.2 The model grid (a), five hydraulic conductivity zones at the top layer (b), Drain package at the top layer (c), Drain package and General-Head Boundary at the bottom layer (d)..... 99

Figure 5.3 Comparison of discharge measurements by YRCC and Water L (a), results of baseflow separation and recorded discharge at Hanjiamao from September 2010 to August 2011 (b), and annual baseflow with stream discharge at Hanjiamao from 1957 to 2011 101

Figure 5.4 Values of $\delta \mathrm{D}$ and $\delta^{18} \mathrm{O}$ in surface water, spring water, groundwater, and the precipitation in summer and winter at nearby stations in GNIP. The local meteoric water line (LMWL; $\delta \mathrm{D}=7 \delta^{18} \mathrm{O}+0.94$ ) is defined based on the data collected from GNIP. .103

Figure 5.5 Piper diagram for river water, surface water, reservoir and drainage lake water, deep and shallow groundwater, and spring water samples taken in 2010 and 2012 104

Figure 5.6 The major chemical compositions in surface water and groundwater water in the Hailiutu catchment in May 2012. 105

Figure 5.7 Isotopic and chemical profile along the Hailiutu River in May 2012. The dots at the top indicate the locations of drainage lake, Tuanjie reservoir, and water diversions at the Hailiutu river 106

Figure 5.8 Estimated groundwater discharge and seepage rates along the Hailiutu River with the chemical profile and measured discharge at Hanjiamao hydrological station in May 2012

Figure 5.9 River discharge, simulated groundwater discharge, and the separated baseflow at Hanjiamao hydrological station from 1968 to 2012 108

Figure 5.10 Comparison between the groundwater discharges calculated by the XXIV 
chemical profile and measured river discharges at Hanjiamao hydrological station and simulated by groundwater flow model along the Hailiutu River.

\section{List of tables}

Table 2.1 Hydraulic engineering works in the Hailiutu catchment............................14

Table 2.2 Land cover in Hailiutu catchment............................................................16

Table 2.3 List of available data in the research catchment.........................................18

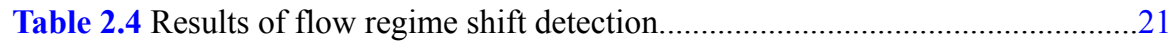

Table 2.5 Harmonic characteristics of monthly discharge and standard deviation at Hanjiamao station.

Table 2.6 Correlation coefficients of monthly precipitation at meteorological stations. .24

Table 2.7 Regime shift detection results of climate variables and crop area .25

Table 2.8 Correlation coefficients among discharge, precipitation, air temperature in growing season, and crop area from 1968 to 2006

Table 3.1 Seepage calculation for the $180-\mathrm{m}$ reach by the three EC-profile methods. .54

Table 4.1 ET values for reference crops and plants for scenario simulations (mm/year) .68

Table 4.2 Precipitation and ET values for reference crops and plants for scenarios 2 and $4(\mathrm{~mm} /$ year$)$. .70

Table 4.3 Annual water balance estimation in the Bulang catchment in $\mathrm{mm} /$ year. . .74

Table 4.4 Comparison of simulated water balance for four scenarios (mm/year).

Table 4.5 Comparison of simulated annual water balance components for scenarios 2 and 4 under different hydrological years (mm/year) .81

Table 5.1 Hydraulic properties used in the models. .99

Table 5.2 Summary of the stable isotopes for water samples in the Hailiutu catchment 


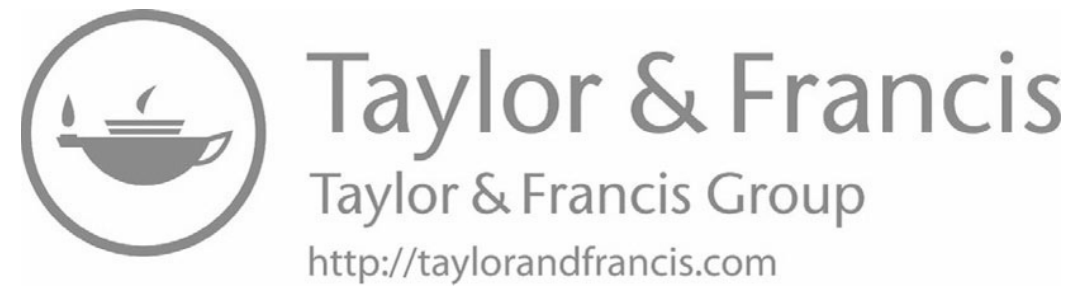




\section{Introduction}

\subsection{Background}

Groundwater and surface water have been considered as isolated components of the hydrological cycle for centuries, but they interact in a variety of ways depending on the physiographic settings (e.g. Winter, 1999, Sophocleous, 2002). Groundwater, as well as surface water resources, are basic conditions for social economic developments worldwide. However, interactions between groundwater and surface water are difficult to measure and quantify (Winter, 1999), which have been considered separately in water resource management and policy formulations. Interactions between groundwater and surface water play very important roles for stream ecosystems (Findlay, 1995) and hence have consequence for ecology, river restoration and conservation (Boulton, et al., 2010) and the protection of groundwater-dependent ecosystems (Zhou, et al., 2013, Bertrand, et al., 2014). However, the relationships between the groundwater and the surface water bodies, such as rivers, lakes, reservoirs, wetlands, have not been fully understood. Climate and human activities were considered to be the two main influential factors by hydrologists and hydrogeologists (Milliman, et al., 2008, Uhlenbrook, 2009, Zhao, et al., 2009, Xu, 2011), but the distinction for them on specific cases remains difficult and debatable.

The recent studies on the interactions between groundwater and surface water utilized multiple methods, including direct field investigations (e.g. Oxtobee and Novakowski, 2002) and measurements (Anderson, et al., 2005) to determine differences in hydraulic heads, chemical and isotopic tracers (e.g. Wenninger, et al., 2008), temperature studies (Conant, 2004, Schmidt, et al., 2007). Remote sensing combined with field observations have been widely employed in hydrological studies by means of upscaling procedures (e.g. Ford, et al., 2007). Due to the temporal and spatial flexibility, numerical modelling approaches have been carried out to study the interactions between groundwater and surface water for transition zone water (Urbano, et al., 2006), the importance of water balance in a mesoscale lowland river catchment (Krause and Bronstert, 2007, Krause, et al., 2007), small 
catchments (Jones, et al., 2008, Guay, et al., 2013) with different scenarios (Gauthier, et al., 2009), to conduct water resources assessment (Henriksen, et al., 2008), to evaluate the impacts of best agricultural management practices (Cho, et al., 2010), and to determine the impacts of climate changes (Scibek, et al., 2007). Apart from natural processes, the anthropogenic effects cannot be neglected in an investigation on the spatial and temporal relationships between groundwater and surface water. However, the quantification of human impacts on the interactions between groundwater and surface water would only be achieved by multiple methods according to previous studies. This thesis is formulated based on summarizing those scientific findings on identification and quantification of interactions between groundwater and surface water.

Integrated water resources management has been implemented in many areas in China with the goal of achieving sustainable development (Ministry of Water Resources, China, 2005). Nevertheless, there are both institutional and technical difficulties that exist when people are facing water shortage, especially for those who live in the arid/semi-arid regions where the groundwater plays a very important role in the water supply for the society and ecosystem. The interactions between groundwater and surface water are the most important part of water cycle in arid and semi-arid region, where the environment is very sensitive to water resources development. Previous studies have shown that water resource scarcity is one of limiting factors for socio-economic development in northwest China. Water management has focused on surface water and groundwater as separate resources for decades in China. The local authorities of Erdos City are concerned more about the ecosystems, sustainable development and river basin management in recent years. However, water management has focused on surface water or groundwater as separate resources. Furthermore, groundwater requirements for ecosystems are not well understood and are often neglected or poorly managed. These interactions can have significant implications for both water quantity and quality (Bordie, et al., 2007). Thus, the understanding of the interactions between the groundwater and surface water on the Erdos plateau becomes crucial to water resources management in terms of both water quantity and quality.

The Erdos plateau administratively belongs to Erdos City of Inner Mongolia and 
the Yulin City of Shaanxi province with an area of approximately $200,000 \mathrm{~km}^{2}$. Half of the area is covered by deserts and bare rocks. The total population is approximately 26 million. The climate is typical inland arid to semi-arid. The precipitation is scarce, with annual average varying from $400 \mathrm{~mm} /$ year in the east to $200 \mathrm{~mm} /$ year in the west. Potential evaporation is very high, ranging from 2000 to $3500 \mathrm{~mm} /$ year. Since the potential evaporation is larger than the precipitation, the surface water resources are limited. The main water resource in the plateau is groundwater (Gao, et al., 2004). Terrestrial ecosystems depend mainly on groundwater. However, overgrazing and cultivation activities accelerated the deterioration of the ecosystem. Desertification, soil loss and land degradation are major problems in the Erdos plateau (Wang, 2008). Located in the middle catchment of the Yellow River system in the centre of China, Erdos is one of new energy bases for China and is targeted as a priority area of western development strategy for China in the 21 st century. Exploitation of coal, natural gas, oil and mineral resources has sped up socio-economic development in the region. The challenge for local governments is to achieve sustainable water resources development to meet increasing water demands from the industry, agriculture, society and ecosystem. This has already overstressed scarce water resources and may have disastrous consequences on fragile ecosystems. Groundwater on the Erdos plateau is historically treated as loss term or static storage in surface water-oriented water balance management. The neglect of groundwater and surface water interactions has caused depletion of stream flows, aquifers and degradation of groundwater-dependent ecosystems. It is increasingly recognized that groundwater and surface water interactions occur in different forms under different physiographic and hydro-climatic conditions. However, these interactions are often altered by anthropogenic interventions, to an extend that is largely unknown.

The Hailiutu River catchment has been selected for detailed research on interactions between groundwater and surface water by the UNESCO-IHE, the Netherlands, China University of Geosciences (Beijing) and Hohai University, China, for its typical characters in terms of the interactions between groundwater and surface water, demands of integrated water resources management as well as the influence of human activities on hydrological process. The river discharge has significantly decreased according to a preliminary analysis. A multi-disciplinary 
approach research has been carried out to quantify spatial and temporal interactions between groundwater and surface water in the Hailiutu River catchment and Bulang sub-catchment. The results should provide a solid scientific basis for an integrated approach for water resources management in river basins, which will hopefully lead to a reversal of the trend of desertification and ecosystem degradation in the Erdos Plateau.

Surface water is connected with groundwater in the Erdos Plateau in many different ways, which leads to high complexity of the hydrological processes in the region. The improved understanding and knowledge of the hydrological processes in interactions between groundwater and surface water will facilitate efficient conjunctive water resources management. A healthy natural environment with sustainable water resources development is a primary condition for sustainable livelihoods of the local population and sustained economic growth and poverty alleviation. Although the interactions between the groundwater and surface are crucial, studies on the relationships between the groundwater abstraction and the discharge in the streams are very limited in this region due to the complexity of the groundwater and surface water systems. Therefore, a better understanding of the interaction between groundwater and surface water is needed for the sustainable and integrated water resources management. This research aims to extend our knowledge of the exchange between groundwater and surface water on Erdos Plateau in order to provide reliable scientific information to decision-makers for the conjunctive sustainable water resources management.

\subsection{Research objectives and approach}

The aim of this study is to understand the underlying processes and to quantify the interactions between groundwater and surface water in the Erdos Plateau.

The specific objectives are:

1) To explore the mechanism of water exchanges between groundwater and surface water at reach scale;

2) To determine the dominant processes and spatial-temporal variations of 
groundwater and surface water interactions in the selected sub-catchment;

3) To provide useful inputs towards a conjunctive groundwater-surface water development plan to meet the water demand for socio-economic development while allocating environmental flows for groundwater dependent ecosystems;

4) To understand historical variations of groundwater levels with the help of a constructed physically-based coupled groundwater and surface water model;

5) To identify and quantify the spatial and temporal variability of interactions between groundwater and surface water in the Hailiutu catchment scale;

6) To estimate the effects of groundwater extraction on the river baseflow and dependent ecosystem in the connected river-aquifer-vegetation system in the Hailiutu catchment; and

7) To distinguish the impacts of different Human activities from climate variety on the interactions between groundwater and surface water at Hailiutu catchment.

To achieve the above objectives, an integrated approach with combination of statistical analysis of historical data, field observation, temperature measurements, chemical and isotopic analysis on groundwater and surface water samples, and numerical modelling have been developed and conducted in the selected Hailiutu catchment and it's tributary Bulang River. After distinguishing the impacts from the climate variables and human activities by a statistical analysis on the historical hydro-meteorological observations, the combined methods with multiple upscaling approaches for investigating interactions between groundwater and surface water in the Hailiutu catchment were applied at the reach and catchment scales. The temporal and spatial variations of interactions between groundwater and surface water have been investigated at the reach scale in the Bulang tributary, sub-catchment, and basin scale. Furthermore, the identification and quantification of components of hydrological processes in the Hailiutu catchment, as well as the impacts of climate and human activities on the interactions between groundwater and surface water, were conducted by applying multiple methods. The research framework is presented in Figure 1.1. 


\subsection{Innovation and challenge}

The hydrological and geomorphological analysis in the semi-arid Hailiutu catchment in Erdos Plateau indicate that the groundwater plays very important role not only in sustaining the hydrological cycle, but also for the ecosystem and society. Recent researches focused more on floods and on the reduction of sediment load in the Yellow river caused by soil and water conservation measurements in the Loess Plateau, and the impacts of climate change on the hydrological processes. However, the quantification of interactions between groundwater and surface water for water resources management has not been studied.

This thesis presents a first study on the hydrological alterations of stream flow by different human activities in Erdos Plateau, which was ascribed to the climate change and soil and water conservation measurements in the previous studies in the middle Yellow river.

First, multiple methods have been applied in this study to determine groundwater-surface water interactions. Considering the limitations of individual field measurement for determining interactions between groundwater and surface water, this thesis adopted multiple methods for identifying and quantifying interactions between groundwater and surface water that consists of hydraulic, temperature, hydrochemistry, isotope and numerical modelling methods. The quantity and quality of the groundwater and surface water can be simultaneously or independently affected by solute exchange among soil, rock, and water. The salt accumulation at top soil due to the evaporation and artificial solute release will also increase the complexity of the chemical components. Hence, the method of estimation of groundwater seepage rates using the chemical profile along the stream in this study provides an innovative efficient method to directly measure the seepage rates along the river with low cost and high reliability. Second, this thesis presents the systematic analysis for the quantification of the interactions between groundwater and surface water at reach, sub-catchment, and catchment scales through different models. Third, the impacts of human activities such as the construction of the reservoirs, water diversion in the flood plain, groundwater exploitation at basin scale and the land use at sub-catchment scale, on the connectivity between groundwater and surface water were analysed. 


\section{Main objectives}

- To understand the variations and driving forces of hydrological processes

- To understand the dominant process of GW-SW interactions

- To identify and quantify the spatial and temporal variations of GW-SW interactions

- To distinguish the impacts of Human activities on GW-SW relationships

\begin{tabular}{l|l} 
- & River profile survey \\
- & Diver morphology \\
- $\quad$ In-situ water quality measurements \\
- Sroundwater level measurements
\end{tabular}

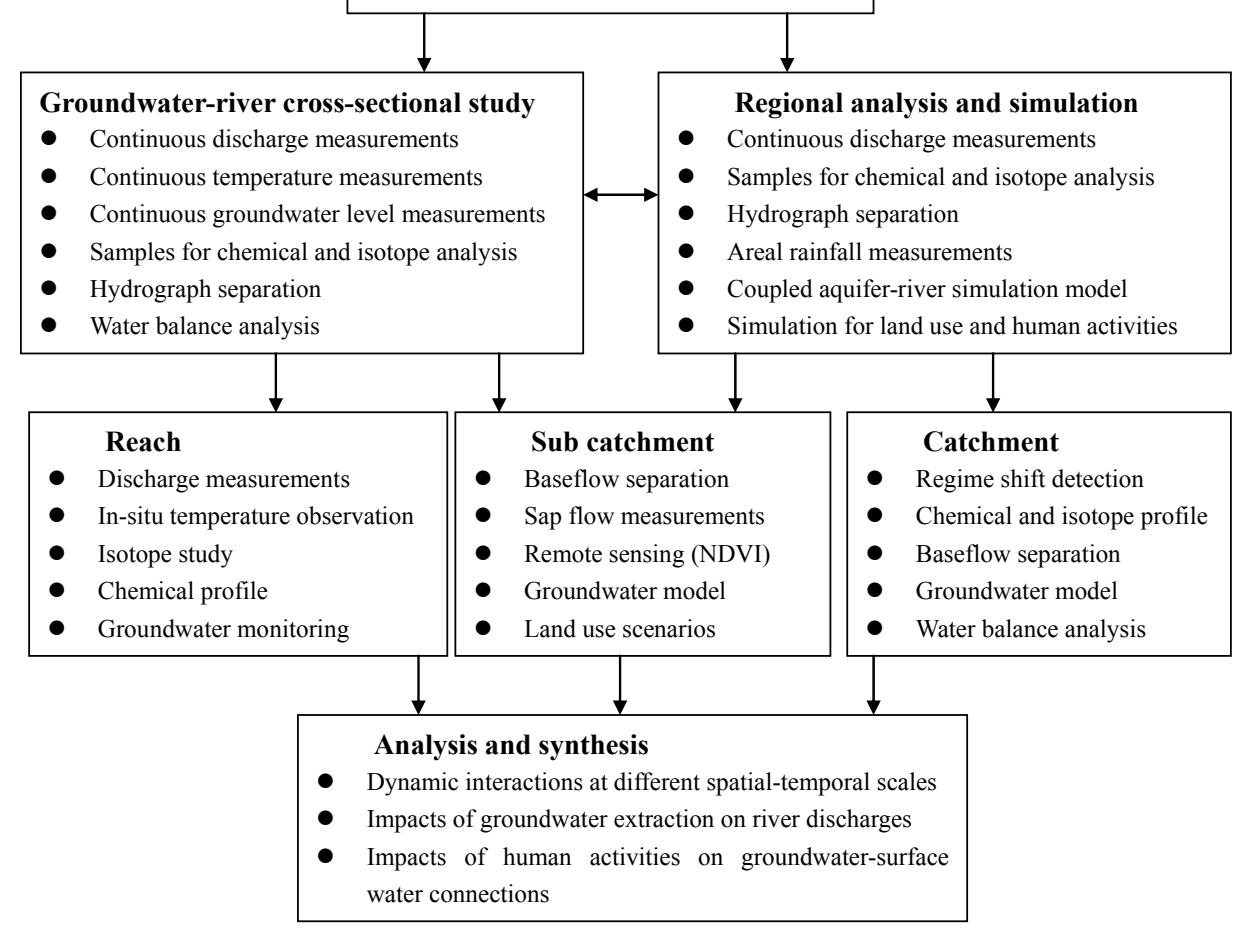

Figure 1.1 Methodologies framework in this study.

Among the scientific challenges in this study, the most significant obstacle is reducing the uncertainties in determining evaporation rate and groundwater recharge at catchment scale during upscaling procedures. Remote sensing and a geographic 
information system (GIS) facilitated estimation of areal evaporation rates from individual experimental observations with Normalized Difference Vegetation Index (NDVI) in this thesis, which provided a novel comprehensive method for hydrological studies at the catchment and sub-catchment scales. Furthermore, conflicts between water use by human activities and the groundwater dependent ecosystem were tackled by scenario analysis of land use changes.

In addition to the scientific challenges on the determination of spatial-temporal variations of groundwater and surface water interactions in the catchment, the impacts of human activities on the available water resources are critical influential facts that need to be quantified. For management challenges, the mutual benefits for ecosystem conservation and water resource use for social and economic developments should be achieved by means of management of groundwater abstractions.

The results of this $\mathrm{PhD}$ study provide valuable references for sustaining conjunctive water resources management in arid and semi-arid regions. The scientific findings during this study also benefit future anti-desertification and ecosystem restoration projects via the land use reformation. The goal of sustainable development could be achieved based on the results of interactions between groundwater and surface water in this thesis.

\subsection{Thesis outline}

This $\mathrm{PhD}$ thesis is formulated based on four peer-reviewed international journal papers. These papers are organized in this thesis as separate chapters. The detailed structure of this thesis is as follows:

Chapter 1 identifies the problems and formulates research objectives.

Chapter 2 addresses general aspects of shifts in the flow regime in the Hailiutu River and possible driving forces (Human activities vs Climate change) in terms of statistical analysis on the characteristics of river discharge, climatic variables, and the crop area. Human interference has significant impacts on the hydrological processes, especially on the interactions between groundwater and surface water. 
Chapter 3 investigates the interactions between groundwater and surface water in the Bulang tributary of the Hailiutu River by means of hydraulic, temperature, hydrochemistry, and isotopic methods, which indicates the groundwater discharges to the rive dominate the hydrological processes in the Bulang tributary. Furthermore, a quantitative estimation of groundwater discharge along a gaining reach with chemical profile and discharge measurements was proposed.

Chapter 4 evaluates the performance of groundwater model with remote sensing and field observation data of actual evaporation for bushes and maize on groundwater-surface water interactions under different land use scenarios within the Bulang sub-catchment. The recommended land use with less water consumption benefits for a shallow groundwater depth and stable river discharge.

Chapter 5 quantifies the spatial variation of human impacts on the groundwater and surface water interactions in the Hailiutu River by comparing simulated groundwater discharges with hydrological observations and calculated groundwater discharge rates with chemical profile measurements along the Hailiutu River.

Chapter 6 draws the syntheses of the previous chapters, the main conclusions, recommendations, and future research areas. 


\section{References}

Abu-Taleb, AA , Alawneh, AJ , Smadi, MM (2007). Statistical analysis of recent changes in relative humidity in Jordan. Am J Environ Sci 3: 75-77.

Adomako, D , Maloszewski, P , Stumpp, C , Osae, S , Akiti, T (2010). Estimating groundwater recharge from water isotope (S2H, S18O) depth profiles in the Densu River basin, Ghana. Hydrological Sciences Journal-Journal des Sciences Hydrologiques 55: 1405-1416.

Ahearn, DS , Sheibley, RW , Dahlgren, RA , Anderson, M , Johnson, J , Tate, KW (2005). Land use and land cover influence on water quality in the last free-flowing river draining the western Sierra Nevada, California. Journal of Hydrology 313: 234-247.

Ala-aho, P , Rossi, PM , Isokangas, E , Klove, B (2015). Fully integrated surface-subsurface flow modelling of groundwater-lake interaction in an esker aquifer: Model verification with stable isotopes and airborne thermal imaging. Journal of Hydrology 522: 391-406.

Anderson, JK , Wondzell, SM , Gooseff, MN , Haggerty, R (2005). Patterns in stream longitudinal profiles and implications for hyporheic exchange flow at the HJ Andrews Experimental Forest, Oregon, USA. Hydrological Processes 19: 2931-2949.

Anderson, MP (2005). Heat as a ground water tracer. Ground Water 43: 951-968.

Arnell, N Reynard, N (1996). The effects of climate change due to global warming on river flows in Great Britain. Journal of Hydrology 183: 397-424.

Ayenew, T , Kebede, S , Alemyahu, T (2008). Environmental isotopes and hydrochemical study applied to surface water and groundwater interaction in the Awash River basin. Hydrological Processes 22:

1548-1563.

Banks, E , Simmons, C , Love, A, Shand, P (2011). Assessing spatial and temporal connectivity between surface water and groundwater in a regional catchment: Implications for regional scale water quantity and quality. Journal of Hydrology 404: 30-49.

Batelaan, O , De Smedt, F , Triest, L (2003). Regional groundwater discharge: phreatophyte mapping, groundwater modelling and impact analysis of land-use change. Journal of Hydrology 275: 86-108. Becker, M , Georgian, T , Ambrose, H , Siniscalchi, J , Fredrick, K (2004). Estimating flow and flux of ground water discharge using water temperature and velocity. Journal of Hydrology 296: 221-233. Bellot, J , Sanchez, J , Chirino, E. , Hernandez, N , Abdelli, F , Martinez, J (1999). Effect of different vegetation type cover on the soil water balance in semi-arid areas of south eastern Spain. Physics and Chemistry of the Earth, Part B: Hydrology, Oceans and Atmosphere , 24 , 353-357.

Ben-Dor, E , Goldshleger, N , Braun, O, Kindel, B , Goetz, A, Bonfil, D , Margalit, N , Binaymini, Y, Karnieli, A , Agassi, M (2004). Monitoring infiltration rates in semiarid soils using airborne hyperspectral technology. International Journal of Remote Sensing 25: 2607-2624.

Bertrand, G , Siergieiev, D , Ala-Aho, P Rossi, P (2014). Environmental tracers and indicators bringing together groundwater, surface water and groundwater-dependent ecosystems: importance of scale in choosing relevant tools. Environmental earth sciences 72: 813-827.

Bethenod, O , Katerji, N , Goujet, R , Bertolini, J , Rana, G (2000). Determination and validation of corn crop transpirationby sap flow measurement under field conditions. Theoretical and Applied Climatology 67: 153-160.

Bewket, W Sterk, G (2005). Dynamics in land cover and its effect on stream flow in the Chemoga watershed, Blue Nile basin, Ethiopia. Hydrological Processes 19: 445-458.

$\mathrm{Bi}, \mathrm{YY}$, Zheng, ZY (2000). The actual changes of cultivated area since the founding of new China. Resources Science, 22, 8-12. (in Chinese with English abstract).

Bobba, A, Bukata, R, Jerome, J (1992). Digitally processed satellite data as a tool in detecting potential groundwater flow systems. Journal of Hydrology 131: 25-62.

Boulton, AJ , Datry, T , Kasahara, T , Mutz, M , Stanford, JA (2010). Ecology and management of the hyporheic zone: stream-groundwater interactions of running waters and their floodplains. Journal of the North American Benthological Society 29: 26-40.

Brodie, R , Sundaram, B , Tottenham, R , Hostetler, S , Ransley, T (2007). An overview of tools for assessing groundwater-surface water connectivity. Canberra, Bureau of Rural Sciences, Australia. Bronstert, A , Niehoff, D , Burger, G (2002). Effects of climate and land - use change on storm runoff generation: present knowledge and modelling capabilities. Hydrological Processes 16: 509-529.

Brown, AE , Zhang, L, McMahon, TA, Western, AW, Vertessy, RA (2005). A review of paired catchment studies for determining changes in water yield resulting from alterations in vegetation. Journal of Hydrology 310: 28-61.

Brunke, M Gonser, T (1997). The ecological significance of exchange processes between rivers and groundwater. Freshwater Biology 37: 1-33. 
Buttle, J (1994). Isotope hydrograph separations and rapid delivery of pre-event water from drainage basins. Progress in Physical Geography 18: 16-41.

Cey, EE , Rudolph, DL , Parkin, GW , Aravena, R (1998). Quantifying groundwater discharge to a small perennial stream in southern Ontario, Canada. Journal of Hydrology 210: 21-37.

Chen, Y, Takeuchi, K , Xu, C , Xu, Z (2006). Regional climate change and its effects on river runoff in the Tarim Basin, China. Hydrological Processes 20: 2207-2216.

Chen, Z , Nie, Z , Zhang, G , Wan, L , Shen, J (2006). Environmental isotopic study on the recharge and residence time of groundwater in the Heihe River Basin, northwestern China. Hydrogeology Journal 14: 1635-1651.

Chiew, FH McMahon, TA (2002). Modelling the impacts of climate change on Australian streamflow. Hydrological Processes 16: 1235-1245.

Cho, J , Mostaghimi, S , Kang, M. (2010). Development and application of a modeling approach for surface water and groundwater interaction. Agricultural Water Management 97: 123-130.

Choi, W-J , Han, G-H , Lee, S-M , Lee, G-T , Yoon, K-S , Choi, S-M , Ro, H-M (2007). Impact of land-use types on nitrate concentration and $\delta 15 \mathrm{~N}$ in unconfined groundwater in rural areas of Korea. Agriculture, Ecosystems \& Environment 120: 259-268.

Christensen, NS , Wood, AW , Voisin, N , Lettenmaier, DP , Palmer, RN (2004). The effects of climate change on the hydrology and water resources of the Colorado River basin. Climatic Change 62: 337-363. Cognard-Plancq, A-L , Marc, V , Didon-Lescot, J-F , Normand, M (2001). The role of forest cover on streamflow down sub-mediterranean mountain watersheds: a modelling approach. Journal of Hydrology 254: 229-243.

Cole, ML , Kroeger, KD , McClelland, JW , Valiela, I (2006). Effects of watershed land use on nitrogen concentrations and $\delta 15$ nitrogen in groundwater. Biogeochemistry 77: 199-215.

Conant, B (2004). Delineating and quantifying ground water discharge zones using streambed temperatures. Groundwater 42: 243-257.

Constantz, J (1998). Interaction between stream temperature, streamflow, and groundwater exchanges in alpine streams. Water Resources Research 34: 1609-1615.

Constantz, J (2008). Heat as a tracer to determine streambed water exchanges. Water Resources Research 44(4).

Constantz J , Stonestrom DA (2003) Heat as a tracer of water movement near streams. US Geological Survey Circular 1-96

Cook, P , Favreau, G , Dighton, J , Tickell, S (2003). Determining natural groundwater influx to a tropical river using radon, chlorofluorocarbons and ionic environmental tracers. Journal of Hydrology 277: 74-88. Cook, PG (2013). Estimating groundwater discharge to rivers from river chemistry surveys. Hydrological Processes 27: 3694-3707.

Costa, MH , Botta, A, Cardille, JA (2003). Effects of large-scale changes in land cover on the discharge of the Tocantins River, Southeastern Amazonia. Journal of Hydrology 283: 206-217.

Courault, D , Seguin, B , Olioso, A (2005). Review on estimation of evapotranspiration from remote sensing data: From empirical to numerical modeling approaches. Irrigation and Drainage Systems 19: 223-249.

Craig, H (1961). Isotopic variations in meteoric waters. Science 133: 1702-1703.

Dahmen E , Hall MJ (1990) Screening of hydrological data: tests for stationarity and relative consistency. International Institute for Land Reclamation and Improvement.

Deng, X-P , Shan, L , Zhang, H , Turner, NC (2006). Improving agricultural water use efficiency in arid and semiarid areas of China. Agricultural Water Management 80: 23-40.

Didszun J , Uhlenbrook S (2008) Scaling of dominant runoff generation processes: Nested catchments approach using multiple tracers. Water Resources Research 44

Doherty, J , Brebber, L Whyte, P (1994). PEST: Model-independent parameter estimation . Watermark Computing, Corinda, Australia 122.

Dong, X , Zhang, X, Yang, B (1997). A preliminary study on the water balance for some sand land shrubs based on transpiration measurements in field condition. Acta Phytoecologica Sinica 21: 208-225.

Dou, L , Huang, M , Hong, Y (2009). Statistical Assessment of the Impact of Conservation Measures on Streamflow Responses in a Watershed of the Loess Plateau, China. Water Resources Management 23: 1935-1949. doi:10.1007/s11269-008-9361-6.

Drogue, G , Pfister, L , Leviandier, T , El Idrissi, A , Iffly, J-F , Matgen, P , Humbert, J , Hoffmann, L (2004). Simulating the spatio-temporal variability of streamflow response to climate change scenarios in a mesoscale basin. Journal of Hydrology 293: 255-269.

Durand, S , Chabaux, F , Rihs, S, Duringer, P , Elsass, P (2005). U isotope ratios as tracers of groundwater inputs into surface waters: example of the Upper Rhine hydrosystem. Chemical Geology 220: 1-19. 
Eckhardt, K Ulbrich, U (2003). Potential impacts of climate change on groundwater recharge and streamflow in a central European low mountain range. Journal of Hydrology 284: 244-252.

Farmer D , Sivapalan M , Jothityangkoon C (2003) Climate, soil, and vegetation controls upon the variability of water balance in temperate and semiarid landscapes: Downward approach to water balance analysis. Water Resources Research 39

Findlay, S (1995). Importance of surface - subsurface exchange in stream ecosystems: The hyporheic zone. Limnology and oceanography, 40: 159-164.

Fohrer, N , Haverkamp, S, Eckhardt, K, Frede, H-G (2001). Hydrologic response to land use changes on the catchment scale. Physics and Chemistry of the Earth, Part B: Hydrology, Oceans and Atmosphere 26: 577-582.

Ford, C. R. , Hubbard, R. M. , Kloeppel, B. D. , \& Vose, J. M. (2007). A comparison of sap flux-based evapotranspiration estimates with catchment-scale water balance. Agricultural and Forest Meteorology 145: 176-185.

Fu, G , Charles, SP , Viney, NR , Chen, S , Wu, JQ (2007). Impacts of climate variability onstream flow in the Yellow River. Hydrological Processes 21: 3431-3439.

Furukawa, Y , Inubushi, K, Ali, M , Itang, A , Tsuruta, H (2005). Effect of changing groundwater levels caused by land-use changes on greenhouse gas fluxes from tropical peat lands. Nutrient Cycling in Agroecosystems 71: 81-91.

Gao, H , Wang, X , Yang, G (2004). Sustainable Exploitation and Utilization of Water Resources in Erdos City. Site Investigation Science and Technology 2: 005.

Gates, JB , Edmunds, W , Ma, J , Scanlon, BR (2008). Estimating groundwater recharge in a cold desert environment in northern China using chloride. Hydrogeology Journal 16, 893-910.

Gauthier, M , Camporese, M , Rivard, C , Paniconi, C , Larocque, M (2009). A modeling study of heterogeneity and surface water-groundwater interactions in the Thomas Brook catchment, Annapolis Valley (Nova Scotia, Canada). Hydrology and Earth System Sciences 13: 1583-1596.

Ge, Y Boufadel, MC (2006). Solute transport in multiple-reach experiments: Evaluation of parameters and reliability of prediction. Journal of Hydrology 323: 106-119.

Gellens, D Roulin, E (1998). Streamflow response of Belgian catchments to IPCC climate change scenarios. Journal of Hydrology 210: 242-258.

Groeneveld, DP (2008). Remotely-sensed groundwater evapotranspiration from alkali scrub affected by declining water table. Journal of Hydrology 358: 294-303.

Groeneveld, DP , Baugh, WM , Sanderson, JS , Cooper, DJ (2007). Annual groundwater evapotranspiration mapped from single satellite scenes. Journal of Hydrology 344: 146-156.

Guay, C , Nastev, M , Paniconi, C , Sulis, M (2013). Comparison of two modeling approaches for groundwater-surface water interactions. Hydrological Processes 27: 2258-2270.

Guggenmos, M , Daughney, C , Jackson, B , Morgenstern, U (2011). Regional-scale identification of groundwater-surface water interaction using hydrochemistry and multivariate statistical methods,

Wairarapa Valley, New Zealand. Hydrology and Earth System Sciences 15: 3383-3398.

Guo, H , Hu, Q , Jiang, T (2008). Annual and seasonal streamflow responses to climate and land-cover changes in the Poyang Lake basin, China. Journal of Hydrology 355: 106-122.

Guidance of further institutional innovation on water management (2005) Ministry of Water Resources, China

Harbor, JM (1994). A practical method for estimating the impact of land-use change on surface runoff, groundwater recharge and wetland hydrology. Journal of the American Planning Association 60: 95-108. Haria, AH Shand, P (2004). Evidence for deep sub-surface flow routing in forested upland Wales:

implications for contaminant transport and stream flow generation. Hydrology and Earth System Sciences 8: 334-344.

Harvey, JW , Wagner, BJ , Bencala, KE (1996). Evaluating the reliability of the stream tracer approach to characterize stream - subsurface water exchange. Water Resources Research 32: 2441-2451.

Hatch, CE , Fisher, AT , Ruehl, CR , Stemler, G (2010). Spatial and temporal variations in streambed hydraulic conductivity quantified with time-series thermal methods. Journal of Hydrology 389: 276-288.

Hayashi, M Rosenberry, DO (2002). Effects of ground water exchange on the hydrology and ecology of surface water. Groundwater 40: 309-316.

He, Y, Pu, T , Li, Z , Zhu, G , Wang, S , Zhang, N , Xin, H , Theakstone, WH , Du, J (2010). Climate change and its effect on annual runoff in Lijiang Basin-Mt. Yulong Region. China. Journal of Earth Science 21: 137-147.

Hendricks Franssen H , Brunner P , Makobo P , Kinzelbach W (2008) Equally likely inverse solutions to a groundwater flow problem including pattern information from remote sensing images. Water Resources Research 44 
Henriksen, HJ , Troldborg, L , Hojberg, AL, Refsgaard, JC (2008). Assessment of exploitable groundwater resources of Denmark by use of ensemble resource indicators and a numerical groundwater-surface water model. Journal of Hydrology 348: 224-240.

Hongve, D (1987). A revised procedure for discharge measurement by means of the salt dilution method. Hydrological Processes 1: 267-270.

Hou, G , Liang, Y , Su X , Zhao Z, Tao Z, Yin L , Yang Y , Wang X (2008). Groundwater systems and resources in the Ordos Basin, China. Acta Geologica Sinica (English Edition) 82: 1061-1069.

Hou, L, Wenninger, J , Shen, J , Zhou, Y, Bao, H , Liu, H (2014). Assessing crop coefficients for Zea mays in the semi-arid Hailiutu River catchment, northwest China. Agricultural Water Management 140: 37-47.

Hu, LT , Chen, CX , Jiao, JJ , Wang, ZJ (2007). Simulated groundwater interaction with rivers and springs in the Heihe river basin. Hydrological Processes 21: 2794-2806.

Hu, LT , Wang, ZJ , Tian, W , Zhao, JS (2009). Coupled surface water-groundwater model and its application in the Arid Shiyang River basin, China. Hydrological Processes 23: 2033-2044.

$\mathrm{Hu}, \mathrm{Y}$, Maskey, S , Uhlenbrook, S (2012). Trends in temperature and rainfall extremes in the Yellow River source region, China. Climatic Change 110: 403-429.

$\mathrm{Hu}, \mathrm{Y}$, Maskey, S , Uhlenbrook, S, Zhao, H (2011). Streamflow trends and climate linkages in the source region of the Yellow River, China. Hydrological Processes 25: 3399-3411.

Huang, G , Sun, J , Zhang, Y, Chen, Z , Liu, F. (2013). Impact of anthropogenic and natural processes on the evolution of groundwater chemistry in a rapidly urbanized coastal area, South China. Science of the Total Environment 463: 209-221.

Huang J , Zhou Y, Yin L , Wenninger J , Zhang J , Hou G , Zhang E , Uhlenbrook S (2014) Climatic controls on sap flow dynamics and used water sources of Salix psammophila in a semi-arid environment in northwest China. Environmental Earth Sciences: 1-13 doi:10.1007/s12665-014-3505-1

IAEA/WMO (2016) Global Network of Isotopes in Precipitation. TheGNIP Database, Accessible at: http://www.iaea.org/water.Accessed 11 March 2016

Jeong, $\mathrm{CH}$ (2001). Effect of land use and urbanization on hydrochemistry and contamination of groundwater from Taejon area, Korea. Journal of Hydrology 253: 194-210.

Jha, M , Pan, Z , Takle, ES , Gu, R (2004). Impacts of climate change on streamflow in the Upper Mississippi River Basin: A regional climate model perspective. Journal of Geophysical Research: Atmospheres 1984-2012: 109.

Jin, X, Wan, L , Zhang, Y , Xue, Z , Yin, Y (2007). A study of the relationship between vegetation growth and groundwater in the Yinchuan Plain. Earth Science Frontiers 14, 197-203.

Jin, XM , Schaepman, ME , Clevers, JG , Su, ZB , Hu, G (2011). Groundwater depth and vegetation in the Ejina area, China. Arid Land Research and Management 25, 194-199.

Jones J , Sudicky E , McLaren R (2008) Application of a fully - integrated surface - subsurface flow model at the watershed - scale: A case study. Water Resources Research 44

Jothityangkoon, C , Sivapalan, M , Farmer, D (2001). Process controls of water balance variability in a large semi-arid catchment: downward approach to hydrological model development. Journal of Hydrology 254: 174-198.

q Kalbus, E , Reinstorf, F , Schirmer, M (2006). Measuring methods for groundwater? Surface water interactions: a review. Hydrology and Earth System Sciences Discussions 10: 873-887.

Kalma, JD , McVicar, TR , McCabe, MF (2008). Estimating land surface evaporation: A review of methods using remotely sensed surface temperature data. Surveys in Geophysics 29: 421-469.

Katz, BG , Coplen, TB , Bullen, TD , Davis, JH (1997). Use of chemical and isotopic tracers to characterize the interactions between ground water and surface water in mantled karst. Groundwater 35 : 1014-1028.

Kirchner, JW (2003). A double paradox in catchment hydrology and geochemistry. Hydrological Processes 17: 871-874.

Klaus, J McDonnell, J (2013). Hydrograph separation using stable isotopes: Review and evaluation. Journal of Hydrology 505: 47-64.

Krause, S Bronstert, A (2007). The impact of groundwater-surface water interactions on the water balance of a mesoscale lowland river catchment in northeastern Germany. Hydrological Processes 21: 169-184.

Krause, S , Bronstert, A , Zehe, E (2007). Groundwater-surface water interactions in a North German lowland floodplain-implications for the river discharge dynamics and riparian water balance. Journal of Hydrology 347: 404-417.

Krause, S , Jacobs, J , Bronstert, A (2007). Modelling the impacts of land-use and drainage density on the water balance of a lowland-floodplain landscape in northeast Germany. Ecological Modelling 200:

475-492. 
Krein, A De Sutter, R (2001). Use of artificial flood events to demonstrate the invalidity of simple mixing models/Utilisation de crues artificielles pour prouver l'invalidite des modeles de melange simple.

Hydrological Sciences Journal 46: 611-622.

Lamontagne, S, Leaney, FW , Herczeg, AL (2005). Groundwater - surface water interactions in a large semi - arid floodplain: implications for salinity management. Hydrological Processes 19: 3063-3080.

Landon, MK , Rus, DL , Harvey, FE (2001). Comparison of instream methods for measuring hydraulic conductivity in sandy streambeds. Groundwater 39: 870-885.

Langhoff, JH , Rasmussen, KR , Christensen, S (2006). Quantification and regionalization of groundwater-surface water interaction along an alluvial stream. Journal of Hydrology 320: 342-358. Lavers, D , Prudhomme, C. , Hannah, DM (2010). Large-scale climate, precipitation and British river flows: Identifying hydroclimatological connections and dynamics. Journal of Hydrology 395: 242-255. Leblanc, M , Favreau, G , Tweed, S , Leduc, C , Razack, M , Mofor, L (2007). Remote sensing for groundwater modelling in large semiarid areas: Lake Chad Basin, Africa. Hydrogeology Journal 15: 97-100.

Lewandowski J , Angermann L, Nutzmann G, Fleckenstein JH (2011) A heat pulse technique for the determination of small - scale flow directions and flow velocities in the streambed of sand - bed streams. Hydrological Processes 25: 3244-3255.

$\mathrm{Li}, \mathrm{DH} \mathrm{Lv}, \mathrm{FY}$ (2004). The function and economy of shrub in return farmland to forest and grass plan in Yulin. Shanxi forest: No 13 Green forum (in Chinese).

Li H , Brunner P , Kinzelbach W , Li W , Dong X (2009) Calibration of a groundwater model using pattern information from remote sensing data. Journal of Hydrology , 377, 120-130

Li, LJ , Zhang, L, Wang, H, Wang, J , Yang, JW , Jiang, DJ , Li, JY, Qin, DY (2007). Assessing the impact of climate variability and human activities on streamflow from the Wuding River basin in China. Hydrological Processes 21: 3485-3491.

Li, Y , Cui, J , Zhang, T , Okuro, T , Drake, S (2009). Effectiveness of sand-fixing measures on desert land restoration in Kerqin Sandy Land, northern China. Ecological engineering 35: 118-127.

Lin, D-j, Zheng, Z-c , Zhang, X-z , Li, T-x , Wang, Y-d (2011). Study on the Effect of Maize Plants on Rainfall Redistribution Processes. Scientia Agricultural Sinica 44, 2608-2615.

Liu, F , Song, X, Yang, L , Han, D , Zhang, Y, Ma, Y, Bu, H. (2015). The role of anthropogenic and natural factors in shaping the geochemical evolution of groundwater in the Subei Lake basin, Ordos energy base, Northwestern China. Science of the Total Environment 538: 327-340.

Larup, JK, Refsgaard, JC , Mazvimavi, D (1998). Assessing the effect of land use change on catchment runoff by combined use of statistical tests and hydrological modelling: case studies from Zimbabwe. Journal of Hydrology 205, 147-163.

Love, D. , Uhlenbrook, S. , Twomlow, S. , \& Pvd, Zaag (2010). Changing hydroclimatic and discharge patterns in the northern Limpopo Basin, Zimbabwe. Water SA 36: 335-350.

Lowry CS , Walker JF , Hunt RJ , Anderson MP (2007) Identifying spatial variability of groundwater discharge in a wetland stream using a distributed temperature sensor. Water Resources Research 43 Lubczynski, MW Gurwin, J (2005). Integration of various data sources for transient groundwater modeling with spatio-temporally variable fluxes-Sardon study case, Spain. Journal of Hydrology 306: 71-96. Lv, J , Wang, XS , Zhou, Y, Qian, K, Wan, L, Eamus, D, Tao, Z (2013). Groundwater - dependent distribution of vegetation in Hailiutu River catchment, a semi - arid region in China. Ecohydrology 6 , 142-149.

Magilligan, FJ Nislow, KH (2005). Changes in hydrologic regime by dams. Geomorphology 71: 61-78. Maheshwari, B , Walker, KF , McMahon, T (1995). Effects of regulation on the flow regime of the River Murray, Australia. Regulated Rivers: Research \& Management 10, 15-38.

Marimuthu, S. , Reynolds, D , La Salle, C (2005). A field study of hydraulic, geochemical and stable isotope relationships in a coastal wetlands system. Journal of Hydrology 315: 93-116.

Masih I, Uhlenbrook S, Maskey S, Smakhtin V (2011) Streamflow trends and climate linkages in the Zagros Mountains, Iran. Climatic Change: 1-22

Matheussen, B , Kirschbaum, RL , Goodman, IA , O'Donnell, GM , Lettenmaier, DP (2000). Effects of land cover change on streamflow in the interior Columbia River Basin (USA and Canada). Hydrological Processes 14, 867-885.

McCallum, JL , Cook, PG , Berhane, D , Rumpf, C , McMahon, GA (2012). Quantifying groundwater flows to streams using differential flow gaugings and water chemistry. Journal of Hydrology 416: 118-132.

McDonald, MG Harbaugh, AW (1984). A modular three-dimensional finite-difference ground-water flow model . Scientific Publications Company Reston, VA, USA.

McDonald MG , Harbaugh AW (1988) A modular three-dimensional finite-difference ground-water flow model 
McDonnell, J , Bonell, M , Stewart, M , Pearce, A (1990). Deuterium variations in storm rainfall: Implications for stream hydrograph separation. Water Resources Research 26: 455-458.

McLay, C , Dragten, R , Sparling, G , Selvarajah, N (2001). Predicting groundwater nitrate concentrations in a region of mixed agricultural land use: a comparison of three approaches. Environmental Pollution 115: 191-204.

Mermoud, A , Tamini, T, Yacouba, H (2005). Impacts of different irrigation schedules on the water balance components of an onion crop in a semi-arid zone. Agricultural Water Management 77: 282-295. Middelkoop, H, Daamen, K, Gellens, D , Grabs, W , Kwadijk, JCJ , Lang, H, Parmet, BWAH, Schadler, B , Schulla, J , Wilke, K (2001). Impact of Climate Change on Hydrological Regimes and Water Resources Management in the Rhine Basin. Climatic Change 49: 105-128. doi:10.1023/a:1010784727448.

Milliman, J , Farnsworth, K , Jones, P , Xu, K , Smith, L (2008). Climatic and anthropogenic factors affecting river discharge to the global ocean, 1951-2000. Global and Planetary Change 62: 187-194. Mitchell, D , Fullen, M , Trueman, I, Fearnehough, W (1998). Sustainability of reclaimed desertified land in Ningxia, China. Journal of Arid Environments 39: 239-251.

Molenat J , Gascuel-Odoux C (2002). Modelling flow and nitrate transport in groundwater for the prediction of water travel times and of consequences of land use evolution on water quality. Hydrological Processes 16: 479-492.

Moore, R. (2004). Introduction to salt dilution gauging for streamflow measurement Part 2: Constant-rate injection. Streamline Watershed Management Bulletin 8: 11-15.

Mu, Q , Zhao, M , Running, SW (2011). Improvements to a MODIS global terrestrial evapotranspiration algorithm. Remote Sensing of Environment 115, 1781-1800.

Munch, Z Conrad, J (2007). Remote sensing and GIS based determination of groundwater dependent ecosystems in the Western Cape, South Africa. Hydrogeology Journal 15, 19-28.

Neff, R , Chang, H , Knight, CG , Najjar, RG , Yarnal, B , Walker, HA (2000). Impact of climate variation and change on Mid-Atlantic Region hydrology and water resources. Climate Research 14: 207-218.

Negrel, P , Petelet-Giraud, E , Barbier, J , Gautier, E (2003). Surface water-groundwater interactions in an alluvial plain: chemical and isotopic systematics. Journal of Hydrology 277, 248-267.

Nie Z-I , Chen Z-y , Cheng X-x, Hao M-I , Zhang G-h (2005) The chemical information of the interaction of unconfined groundwater and surface water along the Heihe River, Northwestern China. Journal of Jilin University (Earth Science Edition) 35: 48-53

Niehoff, D , Fritsch, U , Bronstert, A (2002). Land-use impacts on storm-runoff generation: scenarios of land-use change and simulation of hydrological response in a meso-scale catchment in SW-Germany. Journal of Hydrology 267: 80-93.

Oxtobee J , Novakowski K (2002) A field investigation of groundwater/surface water interaction in a fractured bedrock environment. Journal of Hydrology 269: 169-193

Paulsen, RJ , Smith, CF , O'Rourke, D , Wong, TF (2001). Development and evaluation of an ultrasonic ground water seepage meter. Ground Water 39: 904-911.

Payn, R , Gooseff, M , McGlynn, B , Bencala, K, Wondzell, S (2009). Channel water balance and exchange with subsurface flow along a mountain headwater stream in Montana, United States. Water Resources Research 45.

Petelet-Giraud, E , Negrel, P , Gourcy, L , Schmidt, C , Schirmer, M (2007). Geochemical and isotopic constraints on groundwater-surface water interactions in a highly anthropized site. The Wolfen/Bitterfeld megasite (Mulde subcatchment, Germany). Environmental pollution 148: 707-717.

Pettitt A (1979) A non-parametric approach to the change-point problem. Applied Statistics: 126-135 Poff, NLR , Bledsoe, BP , Cuhaciyan, CO (2006). Hydrologic variation with land use across the contiguous United States: geomorphic and ecological consequences for stream ecosystems. Geomorphology 79, 264-285.

Rautio, A Korkka-Niemi, K (2011). Characterization of groundwater-lake water interactions at Pyhajarvi, a lake in SW Finland. Boreal Environment Research 16: 363-380.

Rautio, A Korkka-Niemi, K. (2015). Chemical and isotopic tracers indicating groundwater/surface-water interaction within a boreal lake catchment in Finland. Hydrogeology Journal 23: 687-705.

Richter, BD , Baumgartner, JV , Powell, J , Braun, DP (1996). A method for assessing hydrologic alteration within ecosystems. Conservation Biology 10: 1163-1174.

Rientjes, THM , Haile, AT , Mannaerts, CMM , Kebede, E , Habib, E (2010). Changes in land cover and stream flows in Gilgel Abbay catchment, Upper Blue Nile basin - Ethiopia. Hydrol Earth Syst Sci Discuss 7: 9567-9598. doi:10.5194/hessd-7-9567-2010.

Rodgers, P , Soulsby, C , Petry, J , Malcolm, I, Gibbins, C, Dunn, S (2004). Groundwater - surface water interactions in a braided river: a tracer - based assessment. Hydrological Processes 18:

1315-1332. 
Rodionov S (2005) A brief overview of the regime shift detection methods Large-Scale Disturbances (Regime Shifts) and Recovery in Aquatic Ecosystems: Challenges for Management Toward Sustainability ed Velikova V and N Chipev UNESCO-ROSTE/BAS Workshop on Regime Shifts (Varna, Bulgaria), 14"C16 June 2005.

Rodionov, S Overland, JE (2005). Application of a sequential regime shift detection method to the Bering Sea ecosystem. ICES Journal of Marine Science: Journal du Conseil 62: 328-332.

Rodionov, SN (2004). A sequential algorithm for testing climate regime shifts. Geophys Res Lett 31: 9204. Rosenberry, D Pitlick, J (2009). Local-scale spatial and temporal variability of seepage in a shallow gravel-bed river. Hydrological Processes 23: 3306-3318.

Rosenberry DO , LaBaugh JW (2008) Field techniques for estimating water fluxes between surface water and ground water Geological Survey (US).

Rosenberry, DO Morin, RH (2004). Use of an electromagnetic seepage meter to investigate temporal variability in lake seepage. Groundwater 42, 68-77.

Ruehl, C , Fisher, A, Hatch, C , Huertos, ML , Stemler, G , Shennan, C (2006). Differential gauging and tracer tests resolve seepage fluxes in a strongly-losing stream. Journal of Hydrology 330: 235-248.

Salama, R , Hatton, T , Dawes, W (1999). Predicting land use impacts on regional scale groundwater recharge and discharge. Journal of Environmental Quality 28: 446-460.

Scanlon, BR, Reedy, RC , Stonestrom, DA, Prudic, DE , Dennehy, KF (2005). Impact of land use and land cover change on groundwater recharge and quality in the southwestern US. Global Change Biology 11: 1577-1593.

Schmidt, C , Bayer-Raich, M , Schirmer, M (2006). Characterization of spatial heterogeneity of groundwater-stream water interactions using multiple depth streambed temperature measurements at the reach scale. Hydrology and Earth System Sciences Discussions 10: 849-859.

Schmidt, C , Conant, B, Jr , Bayer-Raich, M , Schirmer, M (2007). Evaluation and field-scale application of an analytical method to quantify groundwater discharge using mapped streambed temperatures. Journal of Hydrology 347, 292-307.

Scibek, J , Allen, DM , Cannon, AJ , Whitfield, PH (2007). Groundwater-surface water interaction under scenarios of climate change using a high-resolution transient groundwater model. Journal of Hydrology 333: 165-181.

Scott, RL , James Shuttleworth, W , Goodrich, DC , Maddock, T III (2000). The water use of two dominant vegetation communities in a semiarid riparian ecosystem. Agricultural and Forest Meteorology 105:

241-256.

Selker JS, Thevenaz L, Huwald H, Mallet A, Luxemburg W, Van de Giesen N, Stejskal M, Zeman J , Westhoff M , Parlange MB (2006) Distributed fiber - optic temperature sensing for hydrologic systems.

Water Resources Research 42

Sener, E , Davraz, A , Ozcelik, M (2005). An integration of GIS and remote sensing in groundwater investigations: a case study in Burdur, Turkey. Hydrogeology Journal 13: 826-834.

Shaban, A , Khawlie, M , Abdallah, C (2006). Use of remote sensing and GIS to determine recharge potential zones: the case of Occidental Lebanon. Hydrogeology Journal, 433-443.

Silliman, SE , Ramirez, J , McCabe, RL (1995). Quantifying downflow through creek sediments using temperature time series: One-dimensional solution incorporating measured surface temperature. Journal of Hydrology 167: 99-119.

Sklash, MG Farvolden, RN (1979). The role of groundwater in storm runoff. Journal of Hydrology 43 : 45-65.

Sloto RA , Crouse MY (1996) HYSEP, a computer program for streamflow hydrograph separation and analysis US Department of the Interior, US Geological Survey

Snyman, H Fouche, H (1991). Production and water-use efficiency of semi-arid grasslands of South Africa as affected by veld condition and rainfall. Water SA 17: 263-268.

Sophocleous, M (2002). Interactions between groundwater and surface water: the state of the science. Hydrogeology Journal 10: 52-67.

Steele-Dunne, S, Lynch, P, McGrath, R , Semmler, T , Wang, S, Hanafin, J, Nolan, P (2008). The impacts of climate change on hydrology in Ireland. Journal of Hydrology 356: 28-45.

Stisen, S , Jensen, KH , Sandholt, I, Grimes, DI (2008). A remote sensing driven distributed hydrological model of the Senegal River basin. Journal of Hydrology 354: 131-148.

Taylor W (2000) Change-Point Analyzer 2.3 software package. Taylor Enterprises, Libertyville, IL .

Taylor WA (2000) Change-point analysis: a powerful new tool for detecting changes. preprint. Available at http://www.variation.com/cpa/tech/changepoint.html

Thodsen, $\mathrm{H}$ (2007). The influence of climate change on stream flow in Danish rivers. Journal of Hydrology 333: $226-238$. 
Timilsena, J , Piechota, T , Tootle, G , Singh, A (2009). Associations of interdecadal/interannual climate variability and long-term colorado river basin streamflow. Journal of Hydrology 365: 289-301.

$\mathrm{Tu}, \mathrm{M}$. (2006). Assessment of the effects of climate variability and land use change on the hydrology of the Meuse river basin . Institute for Water Education: UNESCO-IHE.

Tweed, SO , Leblanc, M , Webb, JA , Lubczynski, MW (2007). Remote sensing and GIS for mapping groundwater recharge and discharge areas in salinity prone catchments, southeastern Australia.

Hydrogeology Journal 15: 75-96.

Uhlenbrook S (2009) Climate and man-made changes and their impacts on catchments. Water Policy

Uhlenbrook S , Frey M , Leibundgut C , Maloszewski P (2002) Hydrograph separations in a mesoscale mountainous basin at event and seasonal timescales. Water Resources Research 38: 31-31-31-14

Uhlenbrook, S Hoeg, S (2003). Quantifying uncertainties in tracer - based hydrograph separations: a case study for two-, three- and five-component hydrograph separations in a mountainous catchment. Hydrological Processes 17: 431-453.

Urbano, L , Waldron, B , Larsen, D, Shook, H (2006). Groundwater-surfacewater interactions at the transition of an aquifer from unconfined to confined. Journal of Hydrology 321: 200-212.

Vogt, T , Schneider, P , Hahn-Woernle, L , Cirpka, OA (2010). Estimation of seepage rates in a losing stream by means of fiber-optic high-resolution vertical temperature profiling. Journal of Hydrology 380 : 154-164.

Wagner BJ , Harvey JW (2001) Analysing the capabilities and limitations of tracer tests in stream-aquifer systemsImpact of Human Activity on Groundwater Dynamics: Proceedings of an International Symposium (Symposium S3) Held During the Sixth Scientific Assembly of the International Association of Hydrological Sciences (IAHS) at Maastricht, The Netherlands, from 18 to 27 July 2001 IAHS, pp. 191.

Wang, L , Ni, G , Hu, H (2006). Simulation of interactions between surface water and groundwater in Qin River basin. Journal of Tsinghua University (Science and Technology) 46:1979-1986.

Wang, N , Zhang, S , He, J , Pu, J , Wu, X, Jiang, X (2009). Tracing the major source area of the mountainous runoff generation of the Heihe River in northwest China using stable isotope technique. Chinese Science Bulletin 54: 2751-2757.

Wang, S , Tang, C , Song, X, Wang, Q , Zhang, Y, Yuan, R (2014). The impacts of a linear wastewater reservoir on groundwater recharge and geochemical evolution in a semi-arid area of the Lake Baiyangdian watershed, North China Plain. Science of the Total Environment 482: 325-335.

Wang SH , Xu X (2002) Analysis of non-staple economy in China. Ecological Economy: 17-20 (in Chinese)

Wang Y, (2008) The resources saving and environmental protection in construction of Erdos energy base, China sustainable development forum. (Vol. 1, pp. 38-42). (in Chinese)

Wang, Y, Ma, T , Luo, Z (2001). Geostatistical and geochemical analysis of surface water leakage into groundwater on a regional scale: a case study in the Liulin karst system, northwestern China. Journal of Hydrology 246: 223-234.

Waters, P , Greenbaum, D , Smart, PL , Osmaston, H (1990). Applications of remote sensing to groundwater hydrology. Remote Sensing Reviews 4: 223-264.

Wels, C , Cornett, RJ , Lazerte, BD (1991). Hydrograph separation: A comparison of geochemical and isotopic tracers. Journal of Hydrology 122: 253-274.

Wenninger, J , Uhlenbrook, S , Lorentz, S , Leibundgut, C (2008). Identification of runoff generation processes using combined hydrometric, tracer and geophysical methods in a headwater catchment in South Africa/Identification des processus de formation du debit en combinat la methodes hydrometrique, traceur et geophysiques dans un bassin versant sud-africain. Hydrological Sciences Journal 53: 65-80. Westhoff M , Savenije H , Luxemburg W, Stelling G , Van de Giesen N , Selker J , Pfister L , Uhlenbrook $S$ (2007) A distributed stream temperature model using high resolution temperature observations Winter, TC (1995). Recent advances in understanding the interaction of groundwater and surface water. Reviews of Geophysics 33: 985-994.

Winter TC (1999) Ground water and surface water: A single resource US Geological Survey Woessner, WW (2000). Stream and fluvial plain ground water interactions: rescaling hydrogeologic thought. Ground Water 38, 423-429.

Wolfe, BB , Hall, RI , Edwards, TWD , Jarvis, SR , Sinnatamby, RN , Yi, Y. , Johnston, JW (2008). Climate-driven shifts in quantity and seasonality of river discharge over the past 1000 years from the hydrographic apex of North America. Geophysical Research Letters 35: L24402.

Xiao C (2006) Research on Transform Relationship Between Surface Water and Groundwater in Taoer River Fan. Journal of Jilin University(Earth Science Edition) 36: 234-239

$\mathrm{Xu}, \mathrm{J}$ (2011). Variation in annual runoff of the Wudinghe River as influenced by climate change and human activity. Quaternary International 244 , 230-237. 
Xu YH, Zheng YF , Liu XL, Su FR (2009) Climate Change Analysis in Recent 50 Years in Ordos. Meteorology. Journal of Inner Mongolia (in Chinese with English abstract)

Yan, Y , Yang, Z , Liu, Q , Sun, T (2010). Assessing effects of dam operation on flow regimes in the lower Yellow River. Procedia Environmental Sciences 2 , 507-516.

Yang, T , Zhang, Q , Chen, YD , Tao, X , Xu, C , Chen, X (2008). A spatial assessment of hydrologic alteration caused by dam construction in the middle and lower Yellow River, China. Hydrological Processes 22: 3829-3843.

Yang, X , Yan, J , Liu, B (2005). The analysis on the change characteristics and driving forces of Wuding River runoff. Advances in Earth Science , 20, 637-642.

Yang, Z , Li, X , Sun, Y , Liu, L , Zhang, X, Ma, Y (2008). Characteristics of rainfall interception and stemflow for Salix Psammophila in Maowusu sandland, Northwest China. Advances in Water Science 19: 693-698.

Yang, Z , Zhou, Y, Wenninger, J , Uhlenbrook, S (2012). The causes of flow regime shifts in the semi-arid Hailiutu River, Northwest China. Hydrology and Earth System Sciences 16: 87-103.

Yang, Z , Zhou, Y, Wenninger, J , Uhlenbrook, S (2012). The causes of flow regime shifts in the semi-arid Hailiutu River, Northwest China. Hydrology and Earth System Sciences 16: 87-103.

Yang, Z , Zhou, Y , Wenninger, J , Uhlenbrook, S (2014). A multi-method approach to quantify groundwater/surface water-interactions in the semi-arid Hailiutu River basin, northwest China. Hydrogeology Journal $22: 527-541$.

Yang, Z , Zhou, Y, Wenninger, J , Uhlenbrook, S , Wan, L (2015). Simulation of Groundwater-Surface Water Interactions under Different Land Use Scenarios in the Bulang Catchment, Northwest China. Water 7: 5959-5985.

Yin, L , Zhou, Y, Huang, J , Wenninger, J , Zhang, E , Hou, G (2015). Interaction between groundwater and trees in an arid site: Potential impacts of climate variation and groundwater abstraction on trees. Journal of Hydrology 528: 435-448.

Zampella, RA, Procopio, NA , Lathrop, RG , Dow, CL (2007). Relationship of Land - Use/Land - Cover Patterns and Surface - Water Quality in The Mullica River Basin1. JAWRA Journal of the American Water Resources Association 43: 594-604.

Zhang, L , Dawes, W , Walker, G (2001). Response of mean annual evapotranspiration to vegetation changes at catchment scale. Water Resources Research 37: 701-708.

Zhang, Y-K Schilling, K (2006). Increasing streamflow and baseflow in Mississippi River since the 1940s: Effect of land use change. Journal of Hydrology 324: 412-422.

Zhang ZZ , Mu XM , Wang F , Liu YL , Wang J (2009) Relationship Between Cultivated Land Change and Food Security in Yulin City. Research of Soil and Water Conservation (in Chinese with English abstract)

Zhao, FF , Xu, ZX , Zhang, L , Zuo, DP (2009). Streamflow response to climate variability and human activities in the upper catchment of the Yellow River Basin. Science in China Series E: Technological Sciences 52: 3249-3256.

Zhao, X, Huang, Y , Jia, Z , Liu, H , Song, T , Wang, Y, Shi, L, Song, C , Wang, Y (2008). Effects of the conversion of marshland to cropland on water and energy exchanges in northeastern China. Journal of Hydrology 355: 181-191.

Zhou, Y (1996). Sampling frequency for monitoring the actual state of groundwater systems. Journal of Hydrology 180: 301-318.

Zhou, Y, Wenninger, J , Yang, Z, Yin, L, Huang, J , Hou, L , Wang, X , Zhang, D , Uhlenbrook, S (2013). Groundwater-surface water interactions, vegetation dependencies and implications for water resources management in the semi-arid Hailiutu River catchment, China-a synthesis. Hydrology and Earth System Sciences 17: 2435-2447.

Zhou, Y, Wenninger, J , Yang, Z , Yin, L, Huang, J , Hou, L , Wang, X , Zhang, D , Uhlenbrook, S (2013). Groundwater-surface water interactions, vegetation dependencies and implications for water resources management in the semi-arid Hailiutu River catchment, China-a synthesis. Hydrology and Earth System Sciences 17(7): 2435-2447.

Zhou Y , Yang Z, Zhang D , Jin X, Zhang J (2015) Inter-catchment comparison of flow regime between the Hailiutu and Huangfuchuan rivers in the semi-arid Erdos Plateau, Northwest China. 